Florida International University FIU Digital Commons

$7-7-2016$

\title{
Qualities of Informal Leaders, Factors Influencing the Formation of Informal Leadership, and the Paradox of Formal Power
}

Kyungchool Joe

kjoe001@fu.edu,kjoe001@fiu.edu

DOI: 10.25148 /etd.FIDC000714

Follow this and additional works at: https://digitalcommons.fiu.edu/etd

Part of the Organizational Behavior and Theory Commons

\section{Recommended Citation}

Joe, Kyungchool, "Qualities of Informal Leaders, Factors Influencing the Formation of Informal Leadership, and the Paradox of Formal Power" (2016). FIU Electronic Theses and Dissertations. 2610.

https://digitalcommons.fiu.edu/etd/2610 


\section{FLORIDA INTERNATIONAL UNIVERSITY}

Miami, Florida

QUALITIES OF INFORMAL LEADERS, FACTORS INFLUENCING THE

FORMATION OF INFORMAL LEADERSHIP, AND THE PARADOX OF FORMAL POWER

A dissertation submitted in partial fulfillment

of the requirements for the degree of DOCTOR OF PHILOSOPHY

in BUSINESS ADMINISTRATION

by

Kyungchool Joe

2016 
To: Acting Dean Jose M. Aldrich

College of Business

This dissertation, written by Kyungchool Joe, and entitled Qualities of Informal Leaders, Factors Influencing the Formation of Informal Leadership, and the Paradox of Formal Power, having been approved in respect to style and intellectual content, is referred to you for judgment.

We have read this dissertation and recommend that it be approved.

$\begin{array}{r}\hline \text { Juan Sanchez } \\ \hline \text { Mido Chang } \\ \hline \text { Angela Heavey } \\ \hline \text { Karen Paul, Major Professor }\end{array}$

Date of Defense: July 7, 2016

The dissertation of Kyungchool Joe is approved.

\section{Acting Dean Jose M. Aldrich \\ College of Business}

Andrés G. Gil

Vice President for Research and Economic Development and Dean of the University Graduate School

Florida International University, 2016 
(C) Copyright 2016 by Kyungchool Joe

All rights reserved 


\section{DEDICATION}

I dedicate this thesis to my wife, Jun. Without her patience, understanding, support, and most of all love, the completion of this work would not have been possible. 


\section{ACKNOWLEDGMENTS}

I would like to thank my advisor, Karen Paul, for guiding and supporting me for this project. You have been a great dissertation advisor for me.

I would like to thank my dissertation committee members for all of their support, patience, and guidance. 


\begin{abstract}
OF THE DISSERTATION
QUALITIES OF INFORMAL LEADERS, FACTORS INFLUENCING THE FORMATION OF INFORMAL LEADERSHIP, AND THE PARADOX OF FORMAL POWER
\end{abstract}

by

Kyungchool Joe

Florida International University, 2016

Miami, Florida

Professor Karen Paul, Major Professor

Informal leaders can have similar effects on firm performance as formal leaders.

Although informal leadership can play a critical role in organizational functioning, empirical research concerning this issue is scarce. I conceptualized informal leadership as a continuous variable, and tested the relationship between informal leadership and the following variables. First, this study examined how informal leaders can influence over other members, even though they do not possess formal power. Five indicators, i.e., performance, turnover intention, career satisfaction, work engagement, and optimism were selected to assess the qualities of informal leaders as role models. Second, this study advanced our understanding of how demographic factors (i.e., age, educational background, and work experience) contribute to shaping informal leadership. In addition, T-test was chosen to test whether informal leadership is more noteworthy in women than men. Lastly, this study compared the effects of informal and formal leaders on team effectiveness. 


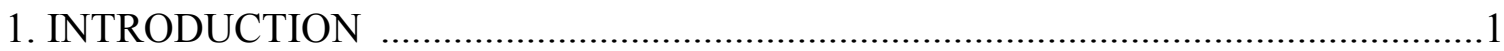

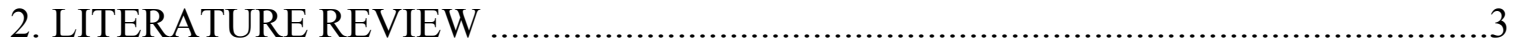

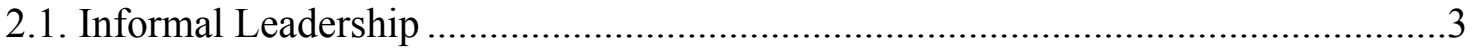

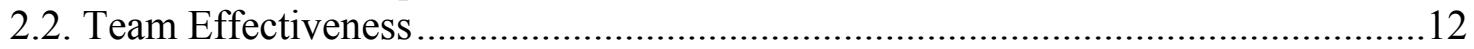

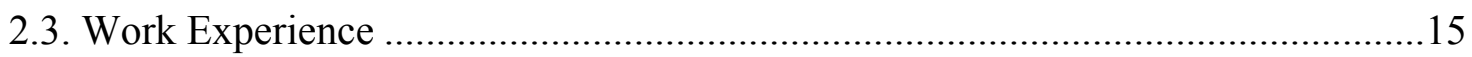

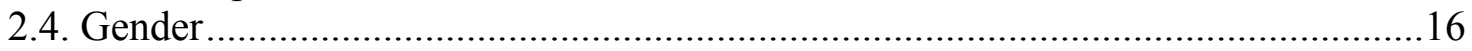

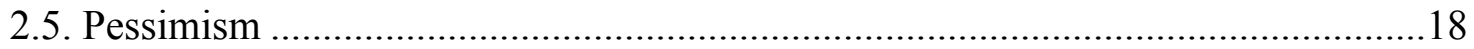

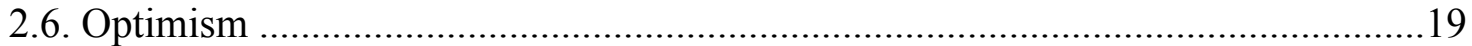

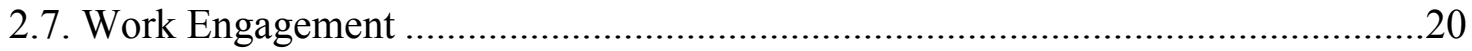

2.8. Organizational Support for Development .......................................................20

2.9. Age

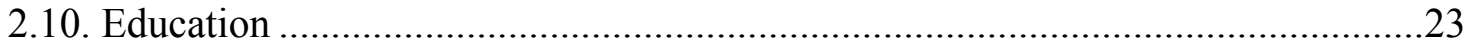

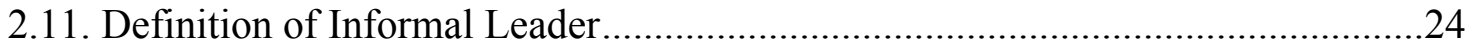

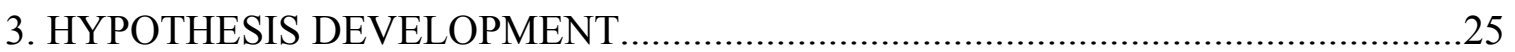

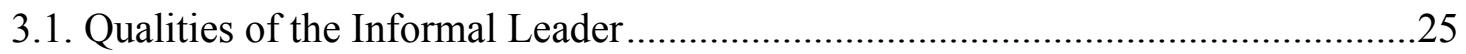

3.2. Factors Influencing the Formation of Informal Leadership....................................31

3.2.1. Age ……........................................................................................

3.2.2. Educational Background ...........................................................................

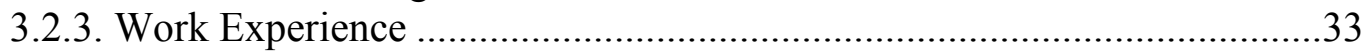

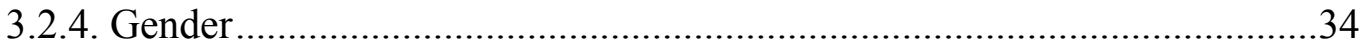

3.2.5. Organizational Support for Development .................................................36

3.3. Informal Leadership and Team Effectiveness ……….........................................38

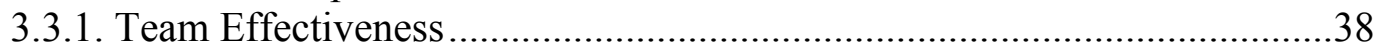

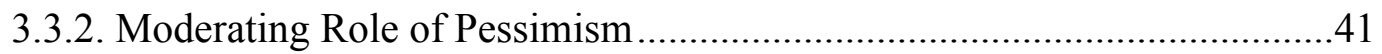

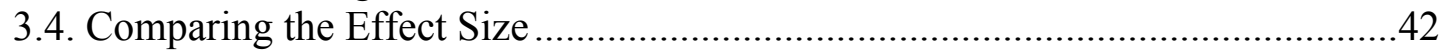

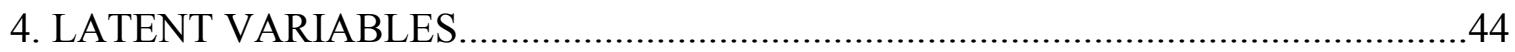

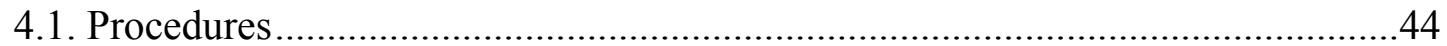

4.2. Informal Leadership (Leadership Group 2) .....................................................4

4.3. Dual Leadership (Leadership Group 1) ………….............................................4

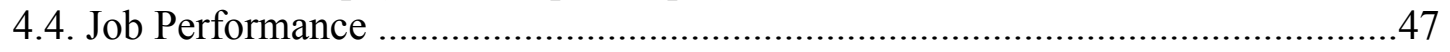

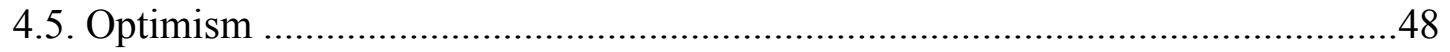

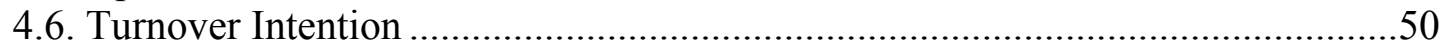

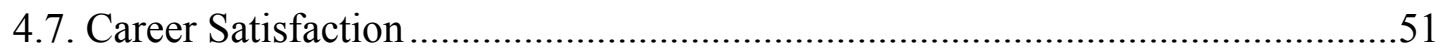

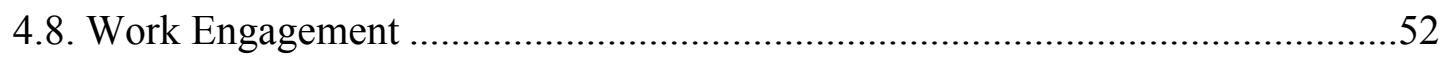

4.9. Organizational Support for Development .......................................................54

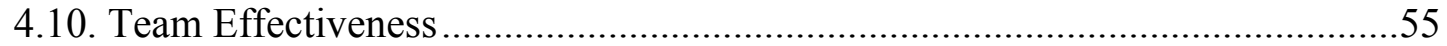

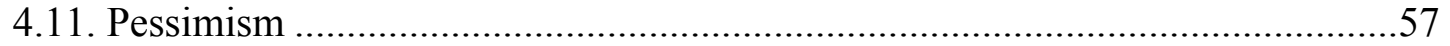

4.12. Demographic Variables ……………………………………………….....5

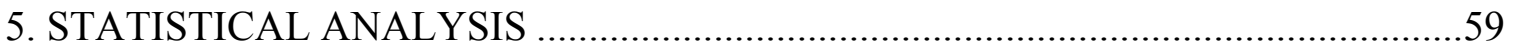




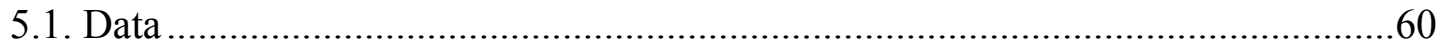

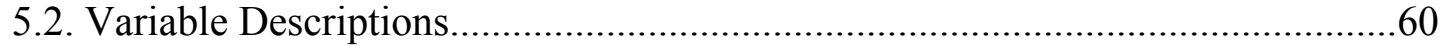

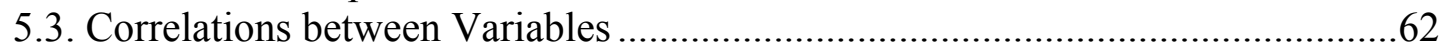

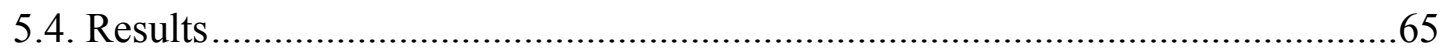

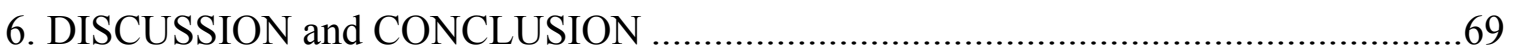

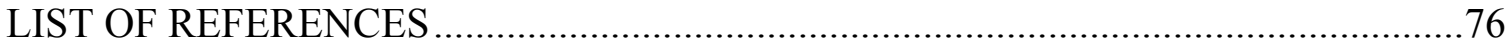

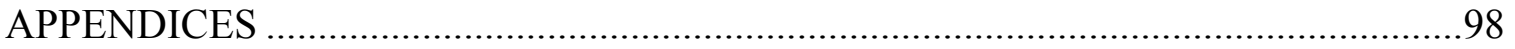

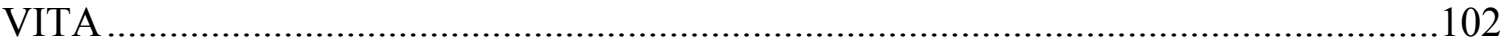




\section{LIST OF TABLES}

TABLE

PAGE

1. Cronbach's Alpha of Each Scale............................................... 45

2. In-Role Performance Items (Williams and Anderson, 1991).....................48

3. Life Orientation Test (Scheier and Carver, 1985)...........................49

4. Four Reverse Coded Items (Scheier and Carver, 1985).......................49

5. Turnover Intention Scale (Knovsky and Cropanzano, 1991).....................51

6. Career Satisfaction Scale(Greenhaus, Parasuraman, and Wormley, 1990) ...........52

7. Work Engagement Scale (Schaufeli, Bakker, and Salanova, 2006).................53

8. Organizational Support for Development Scale (Schein, 1978)...................54

9. Team Effectiveness Scale (Sparrowe, Liden, Wayne, and Kraimer, 2001)............56

10. Beck Hopelessness Scale for Item Review Process.............................57

11. Nine Reverse Code Items from Beck Hopelessness Scale.......................57

12. Average Value of Eleven Variables.....................................61

13. Descriptive Statistics and Correlations for Variables..........................63

14. Descriptive Statistics and Correlations for Variables...........................64

15. Model Summary.....................................................67

16. Multiple Regression Analysis............................................68

17. Comparison Between Men and Women (Hypothesis 5) .............................68

18. Independent Samples Test (Hypothesis 5) ................................68

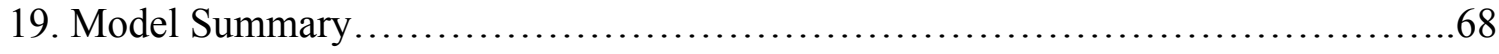

20. Multiple Regression Analysis.........................................69

21. Comparison Analysis of Effect Sizes (Hypothesis 9) .........................69 


\section{INTRODUCTION}

Organizational leadership is more than just a top-down process between formal leaders and organizational members (Mehra, Smith, Dixon, \& Robertson, 2006).

Leadership can occur in several different ways. Leadership includes top-down, bottom-up, and lateral influences (Avolio, Walumbwa, \& Weber, 2009). It is commonly understood that anyone in a group can take a leading role in driving organizational change (Gronn, 2004). This type of leader can appear from any level within an organization. Scholars in the field of organizational behavior have acknowledged informal leadership as an important variable (Bass, 1990; Doloff, 1999) in the functioning of organizations but done little empirical research on informal leadership. Therefore, this perspective complements the traditional emphasis on formal leadership (Day, Gronn, \& Salas, 2004, 2006; Gronn, 2000).

A study of informal leadership will contribute to our understanding of leadership generally. It will help us understand how organizations can benefit from awareness of the impact of informal leadership on team performance and the other dependent variables studied here. Informal leadership does not derive from formal position, but rather derives from the regard individuals have for one another and the extent to which an individual's contribution is considered to have value by others in the organization. Logically, it would seem that informal leaders might affect team and team member performance (Pearce \& Manz, 2005; Ensley, Pearson, \& Pearce, 2003), even though informal leadership does not emerge from organizational position. It is interesting to consider how an informal leader can influence others without formal supervisory authority. 
Informal leadership has been defined in several ways. Informal leadership can be defined with different words such as distributed (Spillane, Halverson, \& Diamond, 2000), emergent (Pescosolido, 2002), shared (Pearce, 2004), team (Day, Gronn, \& Salas, 2006), and collective (Hiller, Day, \& Vance, 2006) leadership but have the same meaning or a similar meaning. These concepts are usually considered in relationship to the team context. In this study, the concept of informal leadership is operationalized beyond the team setting. We conceptualize informal leadership as a continuous variable, deriving from both personal and organizational attributes. Scales to operationalize these attributes are measured by scales from the Age and Generation Study publicly available at ICPSR website (http://www.icpsr.umich.edu/icpsrweb/ICPSR/studies/34837).

First, this study aims to define informal leadership theoretically and methodologically. Second, this study examines how informal leaders can have influence over other organizational members, even though they do not possess formal power. Five indicators, individual performance, turnover intention, career satisfaction, work engagement, and optimism, were used to assess the qualities of informal leaders as role models. Third, this study is intended to advance our understanding of what demographic variables influence the formation of informal leadership. Age, educational degree, and work experience are considered as factors influencing the formation of informal leadership. Additionally, the informal leadership of women is compared with the informal leadership of men. Fourth, this study tests how organizational support for development influences the level of informal leadership within an organization. Fifth, the association between informal leadership and team effectiveness is examined. Sixth, the 
pessimism of employees is tested as a moderator weakening the association between informal leadership and team effectiveness. Last, two leadership groups, i.e., leadership group 1 (informal plus formal, also called dual) and leadership group 2 (only informal) are formed through the classification. The effects of these two leadership groups on team effectiveness are examined to determine whether there is a significant difference in the effects of dual vs. informal leaders.

\section{LITERATURE REVIEW}

\subsection{Informal Leadership}

Leadership means power and ability to exert influence over others (Bass, 1990; Yukl, 1981). A traditional perspective of leadership posited that leadership is a top down, hierarchical process from individual leaders to their followers. This view of leadership essentially counts on position power (Pearce \& Sims, 2002). "Most leadership development efforts have been narrowly focused on individuals who occupy formal leadership positions, or are being groomed to eminently occupy such positions." (Pearce \& Manz, 2005, p. 130) Formal research on organizational leadership dates back to the industrial revolution (Pearce \& Manz, 2005). Conventional thought viewed leaders as commander in the era of scientific management (Gilbreth \& Gilbreth,1924; Taylor, 1911).The direction of leadership influence was thought to flow from individual leaders to their followers, with other variables coming from individual, team, or organizational levels. Followers are confined to their passive roles without having leadership roles. From the conventional perspective of leadership, leaders exert their influence over the team, with the leader positioned external to and superior to the team (Druskat \& Wheeler, 
2003). This concept of focused leadership has dominated leadership studies (Gronn, 2002). From this perspective, leaders work as the initiators and conductors in influence processes (Drath, 2001; Pearce \& Conger, 2003). Regardless of rising objections to this conventional paradigm of leadership research, by the end of the 1970s more than 130 books maintained and even supported the same leadership trend, promoting the message that "leadership is basically doing what the leader wants done" (Rost, 1993, p. 70). Most leadership research focused on this established standpoint and studied how individual leader characteristics, skills, and behaviors influence other organizational variables (Bass, 1990). This traditional concept of leadership is still dominant in leadership research.

In this stream of leadership research, informal leadership has received little academic attention. Scholars have done little to develop the concept of leadership from different angles. Informal leadership has seldom been studied. However, leadership is not an activity that can be monopolized by one single leader. Leadership power can be split and shared across teams or throughout the organization. Team member oriented leadership, in a word, "team leadership" has started to gain more attention in recent years (Bowers \& Seashore, 1966; Day, Gronn, \& Salas, 2006; Gronn, 2002), even though focused leadership was still the dominant paradigm. We are not saying that focused leadership became obsolete. Instead, current and future leadership research must encompass both the classical perspective and more recent studies of informal leadership in order to establish a holistic understanding of leadership processes and outcomes (Day et al., 2004; Pearce \& Sims, 2002) and develop a model of thoughtful leaders, both 
formal and informal (Pearce \& Manz; 2005). Different sources of power held by formal and informal leaders may lead to different ways of executing power. For example, Wheelan (1996) explored the emergence of informal leaders in a setting having formal leaders and found that there are differences in verbal behaviors between formal and informal leaders. The need for shared leadership was introduced and explained in the work of Follett (1924). In the 1950s, the Australian leadership scholar Gibb (1958) proposed the existence of a distributed leadership pattern by stating "Leadership is probably best conceived as a group quality, as a set of functions which must be carried out by the group" (p. 884). In an era dominated by the focused formal leadership perspective, Mann (1959) provided three clarifications concerning how individuals emerge as leaders: (1) by satisfying the needs of others, (2) by fulfilling roles necessary for a group to function successfully, and/or (3) by exhibiting traits that are associated with or trigger socially defined leadership expectations of others. According to McGregor's Theory Y, most workers are genuinely honest and are inclined to do what is right for the organization (McGregor, 1960). Hollander and Julian (1969) argued that individuals who correspond well with followers' ideal type of leader were acknowledged by followers as leaders. Geenleaf (1977) suggested the idea that leaders who are not assigned or designated formally can exert great influence. Behavioral self-management (Thorenson \& Mahoney, 1974), cognitive behavior modification research (Meichenbaum, 1977), social cognitive theory (Bandura,1986), and participative goal-setting research (Erez \& Arad, 1986) also formed the historical bases for the idea of empowering leadership. Manz and Sims (1984) posited that high-performance groups often do not use formal leadership structures. Lawler (1986) studied the organization structure of highly 
involved management in order to motivate workers' participation in organizational processes. Finally, new concepts such as shared leadership, collective leadership, distributed leadership, emergent leadership, and motivation to lead have begun to attract more attention in leadership studies. These rising concepts work as different sources of leadership in team settings. Gronn (1999a \& 1999b) asserted that leadership influence can take the distributed form rather than necessarily taking the concentrated form as had been previously assumed. The newly emerged leadership concepts encouraged followers to participate in influence process. "A relatively new view of leadership posits that all organizational members are capable of leading themselves to some degree" (Pearce \& Manz, 2005).

With these new philosophies, there is no clear-cut role between followers and leaders. Pearce and Manz (2005) argue that shared leadership can be utilized effectively when followers participate in the leadership process. Scholars propose that shared leadership will provide a more appropriate answer for the team-based environment than the traditional, unidirectional, focused, or vertical leadership (Day et al., 2006; Gronn, 2000, 2002; Hoch, 2007). Shared leadership appears to be more strongly associated with team and organizational performance than traditional, focused leadership (Ensley, Hmieleski, \& Pearce, 2006; Hoch, 2007; Pearce \& Sims, 2002). Hiller et al. (2006) propose that leadership power is not exerted by individuals, but rather is a collective process including team members. Collective leadership is embedded in the team. Hiller et al. (2006) investigate the effects of collective team leadership on performance in state Department of Transportation road maintenance teams, finding a positive correlation 
between collective leadership enactment and team performance. Shared leadership is referred as a cooperative influence process enacted by team members and targeted to accomplish common objectives (Hoch, 2007). Pearce (2004, p. 48) define shared leadership as "a simultaneous, ongoing, mutual influence process within a team that is characterized by serial emergence of official as well as unofficial leaders." "Super leadership" is referred to as the behavioral leadership type for others to lead themselves (Manz \& Sims, 1991: 2001).

Early leadership research by Sherif and Sherif (1953) referred to leadership as an emergent group process. Emergent leadership refers to team members exercising remarkable influence over other members of their team, even though they do not possess official power (Schneider \& Goktepe, 1983). Sorrentino and Field (1986) test how achievement-related and affiliation-related motivation sources explain the validity of leadership emergence across time. Collective leadership is not a trait of one person, but instead is a reciprocal team process (Hunt \& Ropo, 1997). Collective leadership is a process whereby leadership is executed by the mechanism of social interactions among members, not by individual heroic or charismatic leaders (Dachler, 1992; Hunt, 2004; Yukl, 1999). Shared leadership is defined as a "team interaction process that involves behaviors in the domain of leadership" (Perry, Pearce, \& Sims, 1999, p. 38). Carson, Tesluk, and Marrone (2007) define shared leadership as " an emergent team property that results from the distribution of leadership influence across multiple team members. It represents a condition of mutual influence embedded in the interactions among team members that can significantly improve team and organizational performance'” (p. 1,218). 
The shared leadership style is when the team, as a single unit, shares and engages in leadership duties demanded by the team to function well (Pearce, 1997). Shared leadership means "a team process where leadership is carried out by the team as a whole, rather than solely by an appointed leader" (Perry et al., 1999, p. 36). If the team has the ability to carry out leadership tasks, team members come to assume the roles that the manager took previously. Without directions from the management level, team members interact in order to "motivate one another, provide feedback on performance, and direct the activities of the sales team" (Perry et al., 1999, p. 35-36). In shared leadership dynamics, individual team members are engaged in influencing the team and team members regarding direction, motivation, and support (Yukl, 1989). Pearce and Sims (2000) observe that shared leadership appears when more than one person participates in team leadership roles. Therefore, the concept of "leadership distribution" can be used in order to operationalize shared leadership appropriately. Team member interactions are expected to increase the likelihood of shared leadership emerging (Carson et al., 2007). By using a sample of 59 consulting firms, Carson et al. (2007) found that shared leadership positively influenced team performance. Shared leadership was measured indirectly by the "group-as-a-whole" or holistic approach in prior studies (Carson et al., 2007; Pearce \& Sims, 2002). Challenging the existing emphasis on the heroic roles of individual leaders, Gronn (2002) suggested distributed leadership. He attempted to demonstrate different patterns of distributed leadership and to categorize them as spontaneous collaboration, intuitive working relations, and institutionalised practice (Gronn, 2002, p. 447). Another contribution that Gronn made was to enlarge the unit of analysis in order to encompass elements and patterns of the new leadership concept, 
distributed leadership. Yukl (1999, pp. 292-293), who criticized focused leadership, said that distributed leadership:

....does not require an individual who can perform all of the essential leadership functions, only a set of people who can collectively perform them. Some leadership functions (e.g., making important decisions) may be shared by several members of a group, some leadership functions may be allocated to individual members, and a particular leadership function may be performed by different people at different times. The leadership actions of any individual leader are much less important than the collective leadership provided by members of the organization.

The distributed leadership perspective proposed by Spillane et al. (2000) "can provide a frame that helps researchers build evocative cases that can be used to help practitioners interpret and think about their ongoing leadership practice" (p. 27) and "can help leaders identify dimensions of their practice, articulate relations among these dimensions, and think about changing their practice" (p. 27).

"Many hands make light work." With the vertical leadership paradigm (Pearce \& Sims, 2002), organizations or teams find it hard to adapt to rapidly changing new environments. In these circumstances, if we pay exclusive attention to formal leadership and ignore the effects of informal leaders, we can have difficulty understanding the leadership influence on organizational constructs in its totality. Specifically, facing a 
challenging demand for innovation and flexibility, organizations have started to consider leadership as jointly coordinated action to accommodate changes (Gronn, 2002). Under this context, some traditional leadership duties are shared with other team members. These newly emerging leadership concepts complement the shortcomings of the traditional perspective by considering the active leadership responsibilities of team members. After understanding the broader concept of leadership, researchers have come to appreciate the importance of both formal and informal leadership (Hunt \& Dodge, 2000).

Until now, research about shared leadership mainly dealt with its direct relationships with other variables (Hoch, Pearce, \& Welzel, 2010). In contrast, other scholars (Hoch, 2007; Pearce \& Conger, 2003) have argued that other variables can influence the relationships between shared leadership and outcome variables as moderators. The intensity of the direct relationship between shared leadership and team variables ranged widely from $\gamma=.15$ (Pearce \& Sims, 2002) to $\gamma=.27$ (Ensley, Hmieleski, \& Pearce, 2006). Age, diversity, and coordination moderated the relationship between shared leadership and team performance (Hoch et al., 2010). The possibility of other moderators should not be overlooked.

The concept of collective leadership is different from the traditional perspective of leadership in several aspects (Hiller et al., 2006). Assigned leaders do not always initiate the collective leadership process. Team members can share leadership roles with other team members through interactions. Various personalities and different levels of abilities among team members can be harmonized and can contribute to collective 
leadership dynamics. During the process, some team members may be more significant as catalysts leading to the rise of emergent leadership.

Researchers have attempted to discover what individual traits, qualities, and abilities lead individuals to be recognized as a leader by other members in a leaderless, autonomous work group (Gough, 1990; Paglis \& Green, 2002). Chan and Drasgow (2001) proposed an integrative theoretical framework in order to examine the relationship between individual differences and various types of leader behaviors. They suggest that individuals differ by their "decisions to assume leadership training, roles, and responsibilities" (p. 482). Trait-based leadership research has utilized five dimensions of personality including conscientiousness, extraversion, agreeableness, emotional stability, and openness to experience (Barrick \& Mount, 1991; Digman, 1990). This individual difference in desire to execute leadership is called motivation to lead (MTL). Lord, De Vader, and Alliger (1986) studied the relation of personality traits to leadership perceptions or the level of leader emergence. Personality attributes and cognitive ability (Taggar, Hackett, \& Saha, 1999), and motivation to lead (Oh, 2012) were determinants of leadership emergence in autonomous work teams. They found that the Big Five OCEAN traits (extraversion, agreeableness, conscientiousness, openness to experience, and emotional stability), along with sociocultural values of collectivism, individualism, past leadership experience, and leadership self-efficacy, appeared to be antecedents of MTL. Oh (2012), studying the leaderless work group setting, posited that team members who have a high motivation to lead (MTL) tend to be recognized as leaders in their work groups. Work team members who display a higher level of leadership motivation and 
take active leadership roles are likely to be perceived as formal or informal leaders (Sorrentino \& Field, 1986).

Since the influence of informal leaders also derives from their positions in the social network (Mechanic, 1962), social network analysis is a proper theoretical framework to use in considering relationship patterns among individuals (Brass, 1995; Sparrowe, Liden, Wayne, \& Kraimer, 2001). Social network analysis can also be applied to measure shared leadership among team members (Mayo, Meindl, \& Pastor, 2003). Two network qualities have been shown to explain team-level aspects of interactions. These are network density and network centralization. Network density is defined as the ratio between the number of current network ties and the total number of possible ties (Hanneman \& Riddle, 2005), and has been shown to relate positively to team outcomes (Bowers \& Seashore, 1966; Mehra et al., 2006). Concerning network centralization, Small and Rentsch (2010) have found a positive relationship between shared leadership and network centralization to team performance using social network theory.

\subsection{Team Effectiveness}

Leadership is an essential element in order to understand the effectiveness of teams (Yeatts and Hyten, 1998; Yukl, 1998) and is an important predictor of team

effectiveness (Cohen \& Bailey, 1997; Kozlowski, Gully, Salas, \& Cannon-Bowers, 1996). Vertical leadership can influence team-level variables such as attitudes, beliefs, and behaviors of team members and can impact team function and process (Bass, 1990; Yukl, 1981). These variables can combine to influence team performance. Shared leadership is one important dimension in "how the selling team displays full empowerment" (Perry et 
al., 1999, p. 36). In addition, shared leadership is depicted as "a dynamic interactive influence process among individuals in groups, for which the objective is to lead one another to the achievement of group or organizational goals or both"' (Pearce \& Conger, 2003, p. 1). The leadership aspects shared among team members (Kozlowski \& Bell, 2003) are often overlooked, although in line with work that uses the paradigm of vertical leadership. The newly emerging styles of leadership including self-leadership (Manz \& Sims, 1993; Pearce \& Manz, 2005), distributed leadership (Barry, 1991), and shared leadership (Katzenbach \& Smith, 1993) have been found to be positively correlated with more effective teams.

Some early leadership scholars emphasized the significant roles of shared leadership (Gibb, 1954; Katz \& Kahn, 1978). More recently, shared leadership has been found to influence team performance through increased information sharing and participation among team members (Mehra et al., 2006). The concept of "shared leadership" has started to attract more attention (Perry et al., 1999; Sivasubramaniam, Murry, Avolio, \& Jung, 2002; Taggar et al., 1999). Shared leadership emerges over time (Carson et al., 2007). More mature teams are likely to engage in this type of leadership (Avolio, Jung, Murry, \& Sivasubramaniam, 1996; Perry et al., 1999). Due to the complexity and ambiguity of teams in today's workplace, it becomes hard for a single leader to carry out all leadership roles (Day et al., 2004). Comparing teams of the past with today, today's teams have more autonomy and power in decision-making (Guzzo \& Dickson, 1996). With the emergence of empowered teams and flattened organizational structures, the conventional models of leadership have been challenged (Mohrman, 
Cohen, \& Mohrman, 1995). In this autonomous team context, informal and emergent leaders influence the cooperation of team members and team performance (Luft, 1984; Neubert, 1999). Teams in which leadership tasks are distributed tend to report increased coordination, collaboration, and commitment (Ensley et al., 2003).

Carson et al. (2007) have examined the conditions that lead to the development of shared leadership. Shared purpose, social support, voice, and external coaching have been identified as indicators for the development of shared leadership. Collective leadership has been presumed to improve team effectiveness, although earlier unpublished studies and recent research did not demonstrate this relationship clearly according to Hiller et al. (2006). However, Perry et al. (1999) argue that since Yukl (1998), academics have attempted to support, conceptually and empirically, the effect of leadership on various types of outcomes, providing a base for developing this link. Empirical studies on shared leadership are very few (Pearce \& Sims, 2002; Pearce, Yoo, \& Alavi, 2004), more conceptual works on the topic have been done (Day et al., 2004; Pearce \& Manz, 2005). The conceptual model developed by Perry et al. (1999) depicts shared leadership "as a unique team process that facilitates the achievement of a number of outcomes, including selling team effectiveness" (p. 36).

Different studies have operationalized collective leadership differently. Neubert (1999) conducted a field study, but could not find a significant relationship between leader dispersion (ratio between the number of informal leaders and the number of team members) and team performance. Zaccaro, Rittman, and Marks (2001) examined how leadership dimensions were associated with team effectiveness and team processes by 
applying a functional team approach. With a sample of 71 management teams, Pearce and Sims (2002) measured cross-functional team members' perceptions of team leadership behavior and looked into how the team members' perceptions affected customer, managerial, and team self-ratings of effectiveness. They concluded that formal leadership was less influential on effectiveness than collective team leadership. Avolio, Jung, Murry, and Sivasubramaniam (1996) analyzed individual level data and posited that perceptions of shared leadership were positively associated with later self-ratings of team effectiveness. Sivasubramaniam et al. (2002) posited that perceptions of shared leadership enhanced later perceptions of team effectiveness. Pearce et al. (2004) posited that shared leadership improved team processes such as social integration and problem solving quality, using a sample of 28 teams. Taggar et al. (1999) found that leaderless student work teams became more effective with a higher mean level of leadership shared by the team leader and team members. They found that the emergent leader did not "ameliorate the negative effects of a staff low in leadership" (p. 899). With respect to top management, Ensley, Hmieleski, and Pearce (2006) examined the impact of vertical leadership and shared leadership in samples of 66 and 154 top management teams and found that both vertical and shared leadership were associated with new venture performance (i.e., revenue growth and employee growth) positively.

\subsection{Work Experience}

Work experience provides opportunities to learn job skills, to improve problemsolving abilities, and to develop networks. Therefore, higher level positions are likely to be given to persons who have more work experience (Lee, 2004). Oh (2012) used the 
term MTL (motivation to lead) to measure emergent leadership. In his study, MTL was defined as "an individual's reaction to the feeling of obligation to lead others" (Oh, 2012, p. 1,454). He hypothesized that people having more experience tended to have higher levels of MTL. However, contrary to expectations, seniority did not have a significant effect. Examining the effects of three demographic variables on wisdom and ethical leadership, Sarros, Cooper, and Hartican (2006) found that wisdom and ethical leadership would be positively correlated with age, experience, and levels of seniority. Cole, Bruch, and Shamir (2009) examined how seniority influenced the impact of leader behavior on followers. In Eastern cultures that emphasize paternalistic leadership and Confucian values, experience and seniority are more appreciated (Cheng, Chou, Wu, Huang, \& Fahr, 2004). From a different angle, Kouzes and Posner (1995, p. 386) claimed that leadership is not dependent on seniority but is "an observable, learnable set of practices."

\subsection{Gender}

Leadership scholars recognize that there are leadership differences between men and women. They have often examined the gender effects on leadership development (Book, 2000). However, previous research findings are mixed (Hoyt, 2010). Therefore, further research and discussion are still needed, although much work has been done. Gender differences have been recognized by scholars from two aspects, biological (Archer, 1996; Reinsch, Rosenblum, Rubin, \& Schulsinger, 1991) and sociopsychological (Beal, 1994). In the similar vein, leadership research on gender has had two theoretical frameworks, social expectation and genetic traits. From childhood, men and women identify their gender roles and are expected to behave following their 
differentiated roles (Eagly \& Wood, 1999). According to social expectation theory, men tend to be task-oriented, but women tend to display social and communal characteristics (Eagly, 1987; Eagly \& Wood, 1982). Social cognitive theory (Bussey \& Bandura, 1999) supports that gender norms and expectations from their families and friends determine children's behaviors and attitudes. Social normative expectation encourages men to become leaders rather than women (Javidan, Dorfman, de Luque, \& House, 2006). Men are expected to be task leaders and women to be social organizers (Kent \& Moss, 1994). Due to this biased social expectation, women continue to face more challenges in developing leadership than men (Eagly \& Karau, 2002). Therefore, with more opportunities to develop their leadership skills, men tend to be more favorably regarded for senior leader positions (Ohlott, Ruderman, \& McCauley, 1994). Men’s higher leadership positions lead them to have more power and network associations, and more resources available (Ridgeway, 1992). In a different perspective, people think that great leaders have more masculine traits (Druskat, 1994). Due to this cognitive bias, women are disadvantaged in advancing to senior leader positions (Eagly \& Carli, 2007). To sum up, two theoretical frameworks suggest that women have been less favored than men for leadership positions. However, with the different thinking of distributed or shared leadership, examining the effect of gender on leadership development can be meaningful.

Women's entry into the professions has continued to increase in recent decades (Vecchio, 2002). Due to the increasing rates of females in the workforce into work groups, gender has become a critical factor to be investigated in the emergence of informal leaders. For this purpose, gender was tested as a variable moderating the 
relationship between individual traits and informal leadership emergence in manufacturing teams (Neubert \& Taggar, 2004). In this study, "a high level of conscientiousness, emotional stability, and team member network centrality predicted informal leadership more for men than for women, but a high level of general mental ability predicted informal leadership more for women than for men.” (p. 175).

Challenging the established thinking that men are superior to women as leaders, Eagly and Karau (1991) posited that women were more likely to emerge as leaders when the team task demanded substantial levels of social interaction.

\subsection{Pessimism}

Pessimism is one of emotional states experienced by employee in the workplace (Thiel, Connelly, \& Griffith, 2012). There are several work-related experiences such as fear of unemployment, unfair compensation, or poor feedback that arouse negative feelings among employees (Andersson \& Bateman, 1997; Bjornstad, 2006; Jensen \& Slack, 2003; Strathdee \& Hughes, 2001). Pessimism causes loss of control and certainty (Connelly, Gaddis, \& Helton-Fauth , 2002). Pessimistic people tend to be reluctant to take action before thinking (Mesquita \& Frijda, 1992; Roseman, 1991). Pessimism reduces confidence (Thiel et al., 2012). Persons with pessimism are likely to call current situations in question and toned reassurance. Pessimistic individuals have difficulty actuating their potential (Keltner, Ellsworth, \& Edwards, 1993). Instead, pessimistic individuals tend to investigate all possible solutions trying to manage unpredictable situations. Pessimism can be distinguished from hopelessness, which is a more intense emotion (Thiel et al., 2012). Hopelessness causes complete withdrawal. 
However, pessimism can contribute to enhancing cognitive ability by triggering deliberation and promoting a more controlled, organized information processing (Kaufmann, 2003; Raghunathan \& Pham, 1999). This can lead to more practical ideas that are readily available for implementation (Thiel et al., 2012).

\subsection{Optimism}

Optimism or hope is the opposite of pessimism. Compared to pessimistic individuals, those who are optimistic are quite eager to take action (Roseman \& Evdokas, 2004). Moods and emotions play a significant role in the leadership process (George, 2000). Optimism is a human virtue or asset that can work as one of the main drivers of behaviors in the workplace (Luthans, 2002; Peterson, 2000). Optimism leads people to think positively, to be more flexible, and to be more creative when they need to generate solutions for organizational problems (Murray, Sujan, Hirt, \& Sujan, 1990). Optimistic people tend to be hopeful and believe that positive events happen more than negative events (Scheier \& Carver, 1985; Salovey \& Birnbaum, 1989). People who experience positive moods tend to become more tolerant in their evaluations and perceptions, more self-confident with their abilities, more helpful for other members, and to believe success will come instead of wasting time blaming negative outcome (e.g. Bower, 1981; Forgas, Bower, \& Moylan, 1990; George, 1991; Rosenhan, Salovey, \& Hargis, 1981). Optimism was found to be positively related to goal-setting and accomplishment, and negatively related to submission, fate, and resignation (Lightsey, 1996). Using a sample of U.S Army Reserve soldiers, Bressler (2006) examined the association between optimism and affective commitment and found the two variables positively correlated. Sales managers' 
positive moods influenced the work groups' quality of customer service, and sales managers in positive moods fostered higher levels of group performance (George, 1995).

\subsection{Work Engagement}

Work engagement became an important variable for organizations striving to elicit employee commitment that goes beyond what is expected and to optimize organizational performance (Masson, Royal, Agnew, \& Fine, 2008). The concept of work engagement captured the interest of scholars because it predicted job performance (Bakker, 2009; Schaufeli \& Salanova, 2007). Work engagement is defined as the extent to which employees invest their physical, emotional, and cognitive personal resources toward their work task roles (Kahn, 1990; Rich, LePine, \& Crawford, 2010; Maslach, Schaufeli, \& Leiter, 2001). Engagement is considered to be "emphatically connected to others in the service of the work they are doing in ways that display what they think and feel, their creativity, their beliefs and values, and their personal connections to others" (Kahn, 1990, p. 700). Schaufeli, Salanova, Gonzalez-Roma, and Bakker (2002) define work engagement as "a positive, fulfilling, work-related state of mind that is characterized by vigor, dedication, and absorption" (p. 74).

\subsection{Organizational Support for Development}

Concerning OSD (organizational support for development), it is believed to be cognitively connected to perceived organizational support (Eisenberger, Huntington, Hutchison, \& Sowa, 1986), specifically, career support (Kraimer \& Wayne, 2004), although those two concepts are still distinguished from each other to some extent. 
Perceived organizational support (POS) is employees' assessment with respect to the extent to which the organization responds to their contributions, job performance, and well-being (Rhoades \& Eisenberger, 2002). POS is defined as "the extent to which employees perceive that their contributions are valued by their organization and that the firm cares about their well-being" (Eisenberger et al., 1986, p. 501). Shanock and Eisenberger (2006) examine the relationship between supervisors' POS and their subordinates' perceptions of supervisor support and report a positive relationship between these two constructs, meaning that supervisors supported by the organization tend to treat their subordinates supportively. POS has been identified as an important predictor of employee turnover (Maertz, Griffeth, Campbell, \& Allen, 2007), of job satisfaction (Eisenberger, Cummings, Armeli, \& Lynch, 1997), of performance (Shanock \& Eisenberger, 2006), and of commitment (Hochwarter, Kacmar, Perrewe, \& Johnson, 2003). Academic research demonstrates that organizational and supervisor supports for development are critical factors that strongly motivate employees to participate in career development programs (Hurtz \& Williams, 2009; Maurer, Pierce, \& Shore, 2002). Perceived organization support is related to organizational justice and trust (Rhoades \& Eisenberger, 2002; Dirks \& Ferrin, 2002). POS mediates the relationship between employees' developmental experiences and job performance (Wayne, Shore, \& Liden, 1997). POS mediates the link between political perceptions and work outcomes (Hochwarter et al., 2003). Going further, Wayne et al. (1997) acknowledge conceptual similarities between POS and leader-member exchange (LMX) and attempt to incorporate the literatures of these two variables by suggesting a model of the antecedents and consequences of POS and LMX. More recently, researchers examined how 
developmental support influences employee work attitudes and behaviors (Ito \& Brotheridge, 2005; Maurer \& Lippstreu, 2008). Practice programs for employees such as participation in decision making processes and autonomy were positively related to commitment and negatively to turnover intentions (Ito \& Brotheridge, 2005). Relationships among subordinates' perception of supervisor support, POS, and employee turnover rate were examined by Eisenberger, Stinglhamber, Vandenberge, Sucharski, and Rhoades (2002). Supportive practices related to human resources such as participation in decision making, reward justice, and growth opportunities were conducive to the growth of POS, and POS mediated the relationship between organizational commitment and job satisfaction (Allen, Shore, \& Griffeth, 2003). Lee and Bruvold (2003) indicated that perceived investment in employees' development (PIED) was positively related to job satisfaction and affective commitment. Furthermore, support for employee development had differential effects on organizational commitment depending on individual learning and performance orientations (Maurer \& Lippstreu, 2008).

\subsection{Age}

Although leaders' age is an interesting topic to be examined in leadership research, scholars have not paid much attention to it. They have not regarded age as an important variable (Zacher, Rosing, \& Frese, 2011). "Data on the effects of managerial age throughout the entire working life span are relatively rare and, where available, inconclusive" (Streufert, Pogash, Piasecki, \& Post, 1990, p. 552). "An electronic literature search of studies published in The Leadership Quarterly over the past 20 years found only one study that treated leader's age explicitly as a theoretically relevant 
concept and not merely as a control variable" (Zacher et al., 2011). Research on leader's age as a demographic variable has been surprisingly unexplored (Walter \& Scheibe, 2013). In addition, the findings concerning the effects of leader's age on behavioral and outcome variables are inconsistent across literature. The world's aging workforce brings the role of age increasing attention among developmental as well as organizational scholars in work settings (Bowen, Noack, \& Staudinger, 2010; Raymo, Warren, Sweeney, Hauser, \& Ho, 2010; Zacher \& Frese, 2009). Many academic works have studied how age affected various types of employee performance (Ng \& Feldman, 2008; Zacher, Heusner, Schmitz, Zwierzanska, \& Frese, 2010). Ng and Feldman (2008) found the positive relationship between age and job performance by utilizing meta-analysis.

Avolio and Gibbons (1988) highlighted the importance of life span approach in leadership. Vecchio (1993, p. 112) found that "employees who were older than their supervisors (a) reported better working relations with their supervisors, (b) evaluated their supervisors more favorably, and (c) received ratings from their supervisors that were not less favorable than other employees." Kanfer and Ackerman (2004) also took the life span approach, providing a framework to understand how age-related developmental changes influence work motivation. Zacher et al. (2011) found that leader's age is positively correlated to leader generativity and negatively associated with follower perceptions of leader effectiveness and follower extra effort.

\subsection{Education}

Barbuto, Fritz, Matkin, and Marx (2007) found that having a master's degree worked as an important predictor for quality leadership roles evidenced in "broader 
critical thinking abilities, higher levels of creativity, stronger communication or even leadership and business acumen" (Gallagher, 2014). Agreeing with Gallagher on the positive effect of education level, Al-Hussammi (2008) reports that level of education is a strong indicator to predict job satisfaction.

\subsection{Definition of Informal Leader}

Sometimes influence in an organization comes not from formal authorities, but rather from personal qualities that are highly regarded by others in the workplace (Yuk1 \& Falbe, 1990, 1991). There have been several attempts to define this type of leadership. First, Howell, Shea, and Higgins (2005) used the term "Champion." Champions often share personality traits such as confidence, enthusiasm, and persistence. They display high levels of personal power, and can exercise a powerful influence on others. Shared or collective leadership (Hiller et al., 2006) and emergent leadership (Pescosolido, 2002; Schneider \& Goktepe, 1983) are ideas closely related to informal leadership. Conger and Pearce (2003) define shared leadership as, "a dynamic, interactive influence process among individuals in groups for which the objective is to lead one another to the achievement of group or organizational goals or both" (p. 1). The term "emergent leader" is defined as "a group member who exerts significant influence over other members of the group, even though the individual lacks formal authority" (Schneider and Goktepe, 1983). 


\section{HYPOTHESIS DEVELOPMENT}

\subsection{Qualities of the Informal Leader}

Even though informal leaders do not possess any formal authority, they are considered leaders within organizations. Which factors lead them to be recognized as informal leaders? In the same vein, this research aims to determine what qualities are associated with informal leadership.

Previous research uncovered key determinants of leadership emergence such as general mental skills and personality, as well as more specific capabilities, talents, and values (Bass, 1990; Bass \& Bass, 2008). The influence of informal leaders comes not from formal authorities, but rather from personal qualities highly regarded by others in the workplace (Yukl \& Falbe, 1990, 1991).

Formal leadership is distinguished from informal leadership by several characteristics that produce significant differences. Scholars have attempted to identify a distinct set of characteristics for informal vs. formal leadership. First, power sources are different. Formal leaders have supervisory authority to influence other people within an organization, whereas the power of informal leaders originates from their knowledge, skills, information superiority, and personality characteristics. The different sources of power held by formal and informal leaders lead to dissimilar ways of executing influence. French and Raven (1959) identified seven different types of power sources and grouped them into two categories, personal (referent, expert, connection) and position power (legitimate, reward, coercive, information). Unlike the influence of formal leaders, the 
influence of informal leaders is based on personal ability. This study focuses on the personal power of the leader, especially referent power. Referent power is an informal leader's ability to lead not by formal authority, but by example and advice. Followers may be influenced by informal leaders, and the influence of an informal leader may affect formal leaders, also.

Informal leadership is leadership that emerges not from organizational position, but from the respect and influence that followers spontaneously accord to an individual. An informal leader in an organization influences others because they regard the informal leader as someone to be respected and someone whose example or opinion is likely to be helpful. Informal leaders possessing greater personal power can exert considerable influence over others (Yukl \& Falbe, 1990, 1991).

Effective leadership leads an organization to be competitive (Zhu, Chew, \& Spangler, 2005). Leadership positively influences job attitudes which in the end positively influence higher performance (Mulki, Jaramillo, \& Locander 2009; Steyrer, Schiffinger, \& Lang, 2008). Positive job attitudes, enhanced by effective leadership contribute to decreasing turnover rate (Sutton \& Griffin, 2004). Authentic leadership positively influenced followers' feelings of inherent work motivation (Avolio \& Gardner, 2005). Transformational leaders support the engagement of their followers (Song, Kolb, Lee, \& Kim, 2012). Research concerning transformational leadership includes two main streams. First is the association between the behavior of low- to mid-level managers and employee performance or attitudes, second is the link between the behavior of top managers and organizational performance (Schaubroeck, Lam, \& Cha, 2007). Trust in 
supervisor has been predicted salesperson's intentions to quit (Mulki, Fernando, \& William, 2006). Riaz and Haider (2010) found that transformational and transactional leadership were positively associated with career satisfaction. However, transformational leadership had a more significant and strong impact $(\rho=.54)$ than transactional leadership. Leadership appeared to be one of the most powerful variables to predict employee work engagement (Harter, Schmidt, \& Hayes, 2002).

George (2000) posited that emotions and moods play a critical role in the leadership process. Optimism is a human propensity that can work as one of the main drivers of organizational behaviors (Luthans, 2002). Optimism is a positive expectation or strong feeling that people have towards their future (Peterson, 2000). With positive mood, people are more engaged in positive and flexible thinking and become more creative in generating constructive ideas for organization (Murray, Sujan, Hirt, \& Sujan, 1990). Optimistic people are confident with the belief that positive outcomes occur more often than negative outcomes (Scheier \& Carver, 1985; Salovey \& Birnbaum, 1989). People who feel positive moods tend to become more lenient in their evaluations and perceptions, more self-confident with their abilities, more supportive for their colleagues, and to have confidence with their success instead of focusing on negative events (e.g. Bower, 1981; Forgas, Bower, \& Moylan, 1990; George, 1991; Rosenhan, Salovey, \& Hargis, 1981). An optimistic person was likely to take a more flexible attitude as a problem-solving approach, using a more comprehensive perspective than one lacking in optimism (Isen \& Baron, 1991; Murray et al., 1990). Leaders are likely to utilize their positive moods and emotions in order to drive improvements in their organizations' 
functioning (George, 2000). Leaders openly express feelings such as enthusiasm and optimism in order to motivate employees (Ashkanasy \& Tse, 2000; Conger \& Kanungo, 1998; Lewis, 2000). According to De Hoogh and Den Hartog (2008), ethical leadership is closely connected to employees' optimism for their future. Transformational leaders make use of their emotions and feel free to share such emotions with their employees (Dubinsky et al., 1995), and at the same time are attentive to how their subordinates feel (Spreitzer \& Quinn, 1996). Peterson, Walumbwa, Byron, and Myrowitz (2009) posited that optimism is an antecedent of transformational leadership. Consistent with this suggestion, Bono and Judge (2004) propose that the appreciation of optimism needs to come first in order to understand the behaviors of transformational leaders. Luthans and Avolio (2003) propose optimism as a critical component for the development of authentic leaders, testing the relationship between entrepreneurs' level of optimism and perceptions of their authentic leadership. Gardner and Schermerhorn (2004: 275) posited that one "task of the authentic leaders is to raise optimism." Authentic leaders strengthen employees' positive emotions by inducing employees to identify with leaders (Avolio, Gardner, Walumbwa, Luthans, \& May, 2004). Positive emotions (i.e., hope and optimism) shared by leaders and followers have critical effects on follower attitudes and behaviors (Avolio et al., 2004). Dolfi and Andrews (2007) found that the optimism experienced by project managers helped them overcome work-related challenges. Optimistic people tend to be confident with their success (Forgas et al., 1990). Working group leaders with a positive mood encourage the prosocial behaviors of group members and decreased group turnover rates (George \& Bettenhausen, 1990). Positive moods positively influenced flexibility on categorization tasks (Isen, Johnson, Mertz, \& Robinson, 1985). Isen et al. 
(1987) suggest that optimistic leaders tend to be more creative, producing novel ideas contrary to current situations.

Previous literature regarding the positive effects of leadership on follower behaviors and attitudes has been reviewed. Leaders supported career satisfaction (Riaz \& Haider, 2010), engagement (Harter et al., 2002; Song et al., 2012) and performance (Schaubroeck et al., 2007) of followers. Leadership contributes to decreasing the followers' intentions to quit (Mulki et al., 2006; Sutton \& Griffin, 2004). The question remains, however, of just how and in what context informal leaders are engaged in the positive influence processes. Ethical leaders "are likely sources of guidance because their attractiveness and credibility as role models draw attention to their modeled behavior." (Brown, Treviño, \& Harrison, 2005, p. 597) Followers observe the words or actions of their supervisors and infer the observations perceptually for their motivation (Epitropaki \& Martin, 2004; Lord, 1985). Leading by example means that a leader is dedicated to his or her work and present guideline to followers about how to sustain their emotional and physical resources toward performance goal, and followers increase their levels of work engagement by observing the attitudes and behaviors of the leaders (Bandura, 1977). One item of a transformational leadership scale (Podsakoff, MacKenzie, Moorman, \& Fetter, 1990) measures subordinates' perceptions of their leaders' behavior by asking “My supervisor leads by example." According to the authentic leadership theory proposed by Avolio et al. (2004), a leader's perceived integrity and authenticity can predict the performance, trust, and engagement. Leader integrity means how a leader's words and deeds are constant over time in connection with the behavior of that leader (Leroy, 
Palanski, \& Simons, 2012; Simons, 1999) Mood contagion activates when one person observes another person's display of mood and imitates the display (Barsade, 2002; Neumann \& Strack, 2000).

Informal leaders lead not by formal authority, but by example and advice. As shown in previous research, followers observe the behaviors of their leaders and tend to establish the direction of their behaviors based on these observations. Through the process of emotional contagion, follower's emotions are influenced by the emotional states of leaders. Engaged, involved, committed employees become more proficient and influential at their jobs. These employees as informal leaders are likely to encourage others to be dedicated, devoted, and committed. Since optimistic and enthusiastic employees tend to act as informal leaders, so we expect informal leaders to also demonstrate more positive feelings than negative feelings. Indicators including performance, optimism, career satisfaction, and work engagement are used as barometers of positive engagement that can be displayed by an informal leader. I expect informal leaders to show lower turnover intention. Therefore, I propose the following:

Hypothesis 1a. Performance is positively related to informal leadership.

Hypothesis 1b. Turnover Intention is positively related to informal leadership.

Hypothesis 1c. Career Satisfaction is positively related to informal leadership.

Hypothesis 1d. Work Engagement is positively related to informal leadership.

Hypothesis 1e. Optimism is negatively related to informal leadership. 


\subsection{Factors Influencing the Formation of Informal Leadership}

Which demographic factors influence the formation of informal leadership? Since little previous research has been done on informal leadership, much of my theory is based on extrapolation from research on other types of leadership and logical analysis. In this study, four demographic variables, i.e., age, educational background, work experience, and gender, are chosen for analysis. Therefore, four hypothetical relationships between these demographic factors and informal leadership are put forward.

\subsubsection{Age}

A few studies have considered how age influence different types of employee performance (Ng \& Feldman, 2008; Zacher et al., 2010). Ng and Feldman (2008), using meta-analysis, found a positive association between age and job performance. Avolio \& Gibbons (1988) emphasized a need for life span approach in leadership research. Vecchio (1993) tested the relationship between employees' age and their working relations with their supervisors, finding a positive slope between the two variables. Zacher, Rosing, and Frese (2011) found that older leaders tended to be more generous but to score lower in follower perceptions of leader effectiveness and to have difficulty encouraging followers to make an extra effort. However, age has not been seen as a major variable in leadership research (Zacher et al., 2011). It is surprising to know that leader's age has seldom been investigated in leadership research (Walter \& Scheibe, 2013). Only one study of all those published in The Leadership Quarterly in the last twenty years adopted the age of leaders as a theoretically meaningful concept (Zacher, Rosing, \& Frese, 2011). Thus, there has 
not been much interest in the association between age and leadership. Furthermore, most leadership research that uses age as a main variable concentrates on formal leadership.

Although leaders' age is an interesting topic to be studied in leadership research, it has not captured much attention from scholars. Leaders' age has been surprisingly unexplored in the field of leadership (Walter \& Scheibe, 2013). Generally speaking, the highest positions of leadership in organizations are held by older persons than those who hold positions at the lower levels of leadership. There may be a similar pattern observed in the relationship between age and informal leadership. As we get older, we tend to become more intellectually and emotionally mature. These types of self-development may contribute to the esteem or confidence that co-workers have in the informal leader's example and advice. Therefore, we expect to observe a positive relationship between age and informal leadership.

Hypothesis 2. Age is positively related to informal leadership.

\subsubsection{Educational Background}

Where does the influence or prestige of informal leaders originate from? Without an officially assigned supervisory role, informal leaders obtain or possess something to influence other employees, whether it is knowledge, social skill, physical attractiveness, or even a fascinating personality. People with more education are likely to possess specialized knowledge or expertise, and simply to be more competent at understanding and interpreting workplace problems. Scholars have attempted to uncover the positive effects of education on performance-related variables. For example, having a master's 
degree contributes to better leadership skills (Gallagher, 2014). In a similar vein, Barbuto et al. (2007) found that the master's degree became a critical factor for outstanding leadership roles. Al-Hussammi (2008) reports that level of education predicts job satisfaction strongly. Therefore, we expect to observe a positive relationship between education and informal leadership.

Hypothesis 3. Educational background is positively related to informal leadership.

\subsubsection{Work Experience}

Work experience provides employee with opportunities to acquire work skills, to learn how to solve work-related problem, and to build relationships. Existing leadership research has viewed tenure or times a particular task is performed as work experience (Borman, Hanson, Oppler, Pulakos, \& White, 1993; Van Iddekinge et al., 2009). Cole et al. (2009) tested how seniority impacted the effect of leader behavior on followers. In Eastern cultures laying emphasis on paternalistic leadership and Confucian belief, seniority is more admired (Cheng et al., 2004). Higher leader positions are likely to be taken by persons having more work experience (Lee, 2004). Enhancing leadership skills via work experience has been an important research topic for last two decades (McCall, 2010). Wisdom and ethical leadership are positively related to levels of seniority (Sarros et al., 2006). From a different perspective, seniority does not necessarily predict leadership (Kouzes and Posner, 1995). In a similar vein, the concept of MTL (motivation to lead) was used by Oh (2012) to assess emergent leadership. He proposed a hypothesis concerning the relationship between length of work experience and level of MTL, but the time spent in a work did not influence MTL in his study. 
Even though some studies could not find a significant relationship between work experience and leadership, seniority has worked as a main predictor explaining leadership in other research. Logic tells us the longer someone works, the more opportunities for career development should be experienced. Organizational members accumulate knowledge, expanding their perspective and experience as informal leaders as time goes by. For these reasons, a positive relation between work experience and informal leadership is hypothesized.

Hypothesis 4. Work experience is positively related to informal leadership.

\subsubsection{Gender}

In the last decade, there has been strong interest in explaining gender differences in leadership (Book, 2000). Social expectation and genetic traits have acted as two main theoretical approaches in leadership and gender research. Social expectation motivates men more to become leaders than women (Javidan et al., 2006). From childhood, men and women are expected to behave based on their different gender roles and come to realize their distinct roles (Eagly \& Wood, 1999). Social expectation theory describes men as more task-oriented and women as more sociable (Eagly, 1987; Eagly \& Wood, 1982). Social normative expectation gives more credit to a man for being a leader than to a women (Javidan et al., 2006). Men are encouraged to be task leaders, while women to be social organizers (Kent \& Moss, 1994). Different expectations work against women in cultivating leadership (Eagly \& Karau, 2002). Having been exposed to more opportunities to cultivate their leadership skills, men are likely to be favorably treated when they assume leadership roles (Ohlott et al, 1994). 
Leadership is said to require more "masculine" traits (Druskat, 1994). Due to this biased social expectation, women go through challenges in exercising leader positions (Eagly et al., 2007). Possessing more social resources, men are expected to have more access to power and influential networks than women, hence to have an advantage in gaining respect as informal leaders (Ridgeway, 1992). Furthermore, women face prejudice (Eagly \& Karau, 2002). Schneer and Reitman (1990) found that two per cent of men and thirty per cent of women reported gender discrimination. The persistence of discrimination and other factors continue to give men advantages in leadership careers. To sum up, two theoretical approaches propose that women have been treated less favorably than men as leaders.

However, researchers have found that women tend to be more democratic and participative in their style when compared to men (Eagly \& Johnson, 1990). Women are more likely to demonstrate social and communal characteristics (Eagly, 1987). Eagly and Karau (1991) posit that women tend to appear more as leaders when a large degree of social interaction is needed for a team task. Wilson (1992) finds that women to be more empathic and have greater verbal and social skills. Although the literature of gender differences has shown that women face more challenging environments in becoming leaders than men, gender differences or effect sizes are relatively small or even minimal (Powell, 1990; Van Engen, Van der Leeden, \& Willemsen, 2001). Women and men were found to be equally effective as leaders by Eagly, Karau, and Makhijani (1995). In addition, the findings are widely variable (Hoyt, 2010). Furthermore, leadership research 
on gender had focused on the traditional type of leadership, formal leadership, rather than informal leadership.

Prior research on leadership support men's superiority as leaders and favorable environments for men in leadership development. However, quantitative results show that gender differences are small and minimal. Additionally, since we are dealing with the topic of informal leadership in this study, more emphatic, participative, and sociable women can exhibit greater informal leadership. Given the different concepts of distributed or shared leadership, studying the relationship between gender and leadership is meaningful. We will compare the mean values of women and men in informal leadership. This hypothesis will explore whether women scores higher than men in informal leadership.

Hypothesis 5. Women will be more likely to be informal leaders than men.

\subsubsection{Organizational Support for Development}

Until now, I have investigated demographic factors that contribute to forming informal leadership. Now I shift the focus from the employee to the company level. Conceptually, organizational support for development (OSD) is connected to perceived organizational support (POS) (Eisenberger, Huntington, Hutchison, \& Sowa, 1986). Employees can evaluate the extent to which the organization cares for their contributions, job performance, and well-being (Rhoades \& Eisenberger, 2002). The assessment of employees on organizational support is used as a measure for POS. POS acts as a critical antecedent of employee's turnover (Maertz et al., 2007), job satisfaction (Allen et al., 
2003; Eisenberger, 1997), and commitment (Hochwarter et al., 2003). POS is associated with organizational justice and trust (Dirks \& Ferrin, 2002; Rhoades \& Eisenberger, 2002). POS is positively related to job performance and work outcomes (Hochwarter et al., 2003; Wayne et al., 1997).

Lee and Bruvold (2003) found that perceived investment in employees' development (PIED) contributed to increasing job satisfaction and affective commitment. Maurer and Lippstreu (2008) found that organizational support for employee development influenced organizational commitment differently according to individual learning and performance orientations. Researchers have examined the positive effects of developmental support on employee work attitudes, behaviors, commitment, and job satisfaction (Ito \& Brotheridge, 2005; Lee \& Bruvold, 2003; Maurer \& Lippstreu, 2008). In addition, according to organizational support theory, employees feel obligated to repay benefits rendered by their companies (Masterson, 2001).

An organization is able to provide a number of learning opportunities such as education and training programs to develop employees' skills and knowledge. Since organizational support has a positive impact on job satisfaction, commitment, justice, and trust, examining the relationship between OSD and informal leadership naturally captured my interest. I feel that learning opportunities can encourage employees’ personal traits as informal leaders. Therefore, this study posits that there is a positive relationship between a company's support for development and informal leadership.

Hypothesis 6. Organizational support for development is positively related to informal leadership. 


\subsection{Informal Leadership and Team Effectiveness}

As described in the introductory section of this study, informal leadership can influence other organizational outcome variables positively. Strong informal leaders can encourage other workers to learn work related knowledge, to perform well, and to master their work. Therefore, informal leaders can affect organizational outcome variables positively like team effectiveness positively.

\subsubsection{Team Effectiveness}

Leadership is positively related to organizational performance measures. Zaccaro et al. (2001) examine how leadership is related to team effectiveness. Eisenhardt and Tabrizi (1995) suggested that project leader power contributes to shortening the cycle time for product development. More specifically, leadership plays an important role in improving team effectiveness (Hackman \& Walton, 1986; Kozlowski et al., 1996). Cohen and Bailey (1997) adopt a heuristic framework for team effectiveness to demonstrate this association. In the leadership literature, various leadership styles on the part of hierarchical, singular leaders have had different effects on team or follower effectiveness (Judge \& Piccolo, 2004; Judge, Piccolo, \& llies, 2004). Judge and Bono (2000) posit that transformational leaders lead with high effectiveness, motivating subordinates.

In the early stage of leadership research, one study defined leadership as an emerging collective process (Sherif \& Sherif, 1953). Other research has considered shared leadership to be one type of informal leadership. Perry et al. (1999) explained shared leadership "as a unique team process that facilitates the achievement of a number 
of outcomes, including selling team effectiveness" (p. 36). This emerging concept of leadership means that team members get involved in leadership procedure, even though they are not assigned to official positions (Schneier \& Goktepe, 1983). Pearce and Sims (2002) surveyed 71 management teams and assessed team members' understandings of cross-functional leadership. They examined how the understandings of team members can influence team effectiveness. Today's teams have become more autonomous, exerting more influence in the decision making process (Guzzo \& Dickson, 1996). Without formal leaders, student work teams tend to share leadership roles and to show higher means in leadership. As empowered teams appear and organizations adopt flat structures, the traditional types of leadership start to encounter resistance (Mohrman et al., 1995). In an autonomous team, the level of cooperation among team members is related to team performance (Luft, 1984; Neubert, 1999). The extent to which each individual member perceives shared leadership appears to have a positive effect on later self-ratings of team effectiveness (Avolio et al., 1996). Consistent with this result, Sivasubramaniam et al. (2002) found perceptions of shared leadership to be positively associated with later assessments of team effectiveness. Pearce et al. (2004) collected data from a sample of 28 teams and found that shared leadership predicted team processes such as problem solving skill and social integration. With leadership roles shared by members, coordination, collaboration, and commitment increases (Ensley et al., 2003).When leadership is shared by team members, it tends to be more strongly related to team and organizational performance than the traditional, vertical type of leadership (Ensley, Hmieleski, \& Pearce, 2006; Hoch, 2007). Ensley et al. (2006) studied 154 top management teams, finding that vertical and shared leadership positively influence the performance measures of new 
ventures (i.e., revenue growth and employee growth). Shared leadership appears to influence team performance through increased information sharing and the participation of team members (Mehra et al., 2006). For example, some studies show that in an organizational hierarchy informal or shared leadership offered by organizational members may have impacts on team or unit-level effectiveness (e.g., Friedrich, Vessey, Schuelke, Ruark, \& Mumford, 2009; Klein, Ziegert, Knight, \& Xiao, 2006). Hiller et al. (2006) argued that shared leadership is a crucial factor for team effectiveness, looking at the association between collective team leadership and the performance of a state department. They found that collective leadership had a positive impact on team performance. Carson et al. (2007) collected data from a sample of 59 consulting firms concerning the relationship between shared leadership and team performance and found the two variables were positively related. Forty-two independent samples of shared leadership and its effect on team effectiveness were examined and meta-analyzed by Wang, Waldman and Zhang (2014). Connected to these findings, Avolio et al. (1996) indicated that recognition of shared leadership was associated with later perceptions of team effectiveness. Other factors affecting levels of team effectiveness are trust (Edmondson, 1999) and cross training. His meta-analytical study found that team-leader popularity had a positive effect on team performance. Consequently, I hypothesize that informal leadership will contribute to team effectiveness.

Hypothesis 7. Informal leadership is positively related to team effectiveness. 


\subsubsection{Moderating Role of Pessimism}

Reacting to situations that they encounter in the workplace, organizational members feel and show emotions. The range of emotions include the spectrum from highly positive, such as optimism and joy, to highly negative emotions, such as frustration and anger (McColl-Kennedy \& Anderson, 2002). Emotion influences other variables such as enthusiasm, turnover, absenteeism, and work engagement. Employees' levels of work engagement are related to their emotional status (Dubinsky et al., 1995). Therefore, leaders who understand emotions seem to inspire subordinates to work more effectively and efficiently (Grossman, 2000) and to enhance team performance.

However, with negative feelings, employees tend to lose their appetite to work and decrease their efforts (Manion, 2000). Self confidence becomes doubtful because of pessimism (Thiel, 2012). The pessimistic person is suspicious of current situations (Keltner, Ellsworth, \& Edwards, 1993). Similarly, those who are discouraged by negative emotions tend to lose confidence in their ability. Sinclair (1988) examined how mood impacts impression formation. He allocated subjects to three emotional sates, elated, neutral, and depressed. When subjects were asked to describe their impression of a target, those in elated moods tended to evaluate the target more positively than those in bad moods (Sinclair, 1988). Furthermore, pessimistic people expect negative events to happen more and positive events to happen less (Bower, 1981; Salovey \& Birnbaum, 1989).

Prior research on shared leadership paid attention to its direct impacts on other variables (Hoch et al., 2010). In this research stream, some scholars (Hoch, 2007; Pearce 
\& Conger, 2003) suggested the possible influence of other variables on this direct link. As suggested, age, diversity, and coordination weakened or strengthened the relationship between shared leadership and team performance as moderators (Hoch et al., 2010). Other variables can cut into this direct link as moderators. Following this line of reasoning, it would seem that the pessimism of employees can act as a moderator by diminishing the association between informal leadership and team effectiveness.

Hypothesis 8. Employees' pessimism weakens the relationship between informal leadership and team effectiveness.

\subsection{Comparing the Effect Size}

Informal leaders can be as influential as formal ones in changing organizational functioning by using their unofficial ties and by exercising social influence (Balkundi \& Kilduff, 2006). However, most leadership research has focused on formal leaders rather than informal leaders. Most existing research simply poses a differentiation of one type from the other. Therefore, a systematic approach on how formal and informal leadership styles work differently within organizations has the potential to contribute to both theory and practice in the area of leadership studies. Leaders, formal or informal, motivate members and direct them toward goals. Both formal and informal leadership styles can contribute to organizational performance. In an organization, leaders can possess the qualities of the two leadership styles. All formal leaders execute different levels of informal leadership. 
Leaders have an effect on firm and team performance as well as cognitive and behavioral outcomes for organizational members. Informal leadership, in combination with formal leadership, can play a critical role changing the levels of these variables. This analysis is intended to advance our understanding of formal and informal leadership, and the similarities or differences in how they affect team performance. The main research question is this: Is there a significant difference in the strengths of supervisors who also report they have informal leadership qualities vs. informal leaders who do not have supervisory responsibilities in influencing team effectiveness? Since formal and informal leaders use different bases of power and authority, and have different methods of affecting other organizational variables, the comparison becomes an interesting research question (Bass \& Steidlmeier, 1999; Fairholm, 1998).

Realistically, some employees assigned with official positions exert both formal and informal leadership, others exert only informal leadership. Employees categorized as formal leaders also marked the extent of their own informal leadership on Likert scales. Formal leaders are those who reported formal supervisory responsibilities. The item asks whether subjects are given formal supervisory responsibilities. Subjects are instructed to respond "Yes" or "No." Different levels of influential power as informal leaders interact with their possession or non-possession of formal authority. Two leadership groups are formed through the classification. Each cell may influence the dependent variables differently. Therefore, Leadership Group 1 indicates respondents who occupy supervisory positions and also report they are informal leaders. Leadership Group 2 indicates informal leaders without formal supervisory positions. It is natural to reason 
that with one more power source, Leadership Group 1 has a stronger impact on team effectiveness than Leadership Group 2.

Hypothesis 9. Individuals who exert both formal and informal leadership will have a stronger effect on team effectiveness than those who exert only informal leadership.

Figure 1

Two Comparison Groups Formed by Formal and Informal Leadership Aspects

\begin{tabular}{|c|c|c|}
\hline & & $\begin{array}{l}\text { Informal Leadership } \\
\text { (Scales: Strongly Agree to Strongly Disagree) }\end{array}$ \\
\hline \multirow{2}{*}{$\begin{array}{l}\bar{\sigma} \\
\text { 틍 } \\
\text { 온 }\end{array}$} & YES & Leadership Group 1 (Informal + Formal) \\
\hline & NO & Leadership Group 2 (Only Informal) \\
\hline
\end{tabular}

\section{LATENT VARIABLES}

\subsection{Procedures}

All of the measures for each variable were derived from the Age and Generations Study, which is a secondary data source. There are 582 questions in the Age and Generations Study. To procure measurement validity, several procedures are suggested. First, for each construct, one commonly used scale was selected. As informal leadership is a new concept created by a new operationalization, the step of selecting a scale is omitted for it. The new selected scale was reviewed cautiously. First, a group of items was sorted from the Age and Generations Study and combined into scales. Initially 
selected measures were examined by the advisory committee for face validity. Through this process, irrelevant items were excluded. Finally, Cronbach's alpha was calculated to check internal consistency between items. Table 1 shows Cronbach's alpha of each scale. Cronbach's alpha provides an estimate of internal consistency. Cronbach's alpha is used to indicate the degree to which a set of test items measure the same construct. All of the values are larger than .7, indicating an acceptable level of internal consistency (George \& Mallery, 2003). We averaged all of the items for each variable to form a composite score to measure that variable. The composite score was loaded for analysis afterward.

\section{Table 1}

Cronbach's Alpha of Each Scale

\begin{tabular}{c|c}
\hline Scale & Cronbach's alpha \\
\hline Informal Leadership & .756 \\
\hline Optimism & .799 \\
\hline Job Performance & .859 \\
\hline Turnover Intention & .767 \\
\hline Career Satisfaction & .918 \\
\hline Work Engagement & .872 \\
\hline Organizational Support for Development & .922 \\
\hline Team Effectiveness & .890 \\
\hline Pessimism & .807
\end{tabular}

\subsection{Informal Leadership (Leadership Group 2)}

This study focuses on informal leadership, relying on self-assessment data collected in the aforementioned study. Even though some informal leaders do not possess any formal authority, they consider themselves to be perceived as leaders within 
organizations. We were interested in the factors that led them to be recognized as informal leaders, so we looked for attitudes and behaviors that would logically be associated with informal leadership in order to construct a relevant scale. Brass (1992) found that the influence of informal leaders originated from their centrality within organizations, with more central individuals likely to be more influential. Consequently, this study used two concepts, centrality and influential power, as guidelines to pick items reflecting informal leadership from the Age and Generations Study. In addition, another model for selecting items relating to informal leadership was provided by Antonakis, Avolio, and Sivassubramaniam (2003), who focused on the self-reported ability of leaders to influence the decisions of followers. Possible survey items in the Age and Generations Study that might indicate informal leadership were reviewed and four sixpoint Likert scale items were selected with responses ranging from "strongly disagree" to "strongly agree." The items include the following:

I have a say in the way my work group performs its tasks.

My coworkers openly share work-related information with me.

I am able to influence decisions that affect my work group.

I am usually invited to important meetings in my organization.

With these four items, a Cronbach's alpha of .756 was calculated, indicating a sufficient level of internal consistency. If two items "My coworkers openly share workrelated information with me" and "I am usually invited to important meetings in my organization" were eliminated, Cronbach's alpha improved, producing a Cronbach's 
alpha of .828. Since statistically significant levels were satisfactory either way, we kept all four items for analysis. Since this study focuses on informal leadership except for analysis of the last hypothesis, respondents reporting that they had supervisory responsibilities were excluded from the sample for analysis of all hypotheses except for the last.

\subsection{Dual Leadership (Leadership Group 1)}

Some members in an organization exercise both formal and informal leadership. Age and Generation study asked respondents if they possess formal supervisory power. Subjects responded "Yes" or "No." The respondents who answered "Yes" for the questionnaire were categorized into Leadership Group 1 meaning that they are formal leaders with different extents of informal leadership. Concerning informal leadership, they also marked on a six-point Likert scale ranging from "strongly disagree" to "strongly agree." Different levels of informal leadership interact with their possession of an officially assigned position.

\subsection{Job Performance}

In-role performance scale has been used to measure job performance (Williams and Anderson, 1991). The scale consists of seven 5-point Likert-type items ( $1=$ never to $5=$ always). The items are shown in Table 2 . The items are reviewed to identify major aspects of job performance. The completion of duty, performance evaluation, and fulfillment of expectation were found to be three major ideas of performance. 
Table 2

In-role Performance Items (Williams and Anderson, 1991)

1. Adequately completes assigned duties

2. Engages in activities that will directly affect his or her performance evaluation

3. Fails to perform essential duties

4. Fulfills responsibilities specified in job description

5. Meets formal performance requirement of the job

6. Neglects aspects of the job he or she is obliged to perform.

7. Performs tasks that are expected of him or her.

Selecting items to measure employee performance was relatively straightforward, since several survey items directly related to this variable. Three five-point Likert items were chosen, all having the term "performance" or "perform" in the question itself with responses ranging from "very poor" to "excellent." These included the following: "How would you rate your job performance, as an individual employee? For example, how well do you perform your job compared to other members of your team?", "Think about your most recent assessment of your job performance or the most recent time you received feedback from your supervisor. How do you think your supervisor would rate your performance, in comparison to other members of your team?", and "How would you rate your performance as a work team member?" Internal consistency between these three items was measured with Cronbach's alpha, which measured .859, indicating a satisfactory level of internal consistency.

4.5 Optimism

Optimism is associated with positive thinking (Akhter, Ghayas, \& Adill, 2013). Optimism is one's positive expectation toward the future (Carver \& Scheier, 2002). 
Optimists believe that positive events will occur in their lives, and this belief enhances their self-confidence (Goldsmith \& Matherly, 1988; Lyubomirsky, Tkach, \& DiMatteo, 2006). Optimists do not give up just because situations are stressful and even experience positive emotions being faced with obstacles (Fredrickson, 2001; Youssef \& Luthans, 2007). This positive outlook allows them to apply more creative solutions in order to handle problems.

Table 3

Life Orientation Test (Scheier \& Carver, 1985)

1. In uncertain times, I usually expect the best.

4. I always look on the bright side of things.

5. I am always optimistic about my future.

11. I am a believer in the idea that "every cloud has a silver lining."

Table 4

Four Reverse Coded Items (Scheier \& Carver, 1985)

3. If something can go wrong for me, it will

8. I hardly ever expect things to go my way

9. Things never work out the way I want them to

12. I rarely count on good things happening to me

The Life Orientation Test (LOT) has been used most frequently to assess optimism (Scheier \& Carver, 1985). The short version of LOT Scale (1985) was used as reference in order to select appropriate items from the Age and Generations Study. Originally, the LOT scale consisted of twelve 5-point Likert-type items ( $1=$ strongly disagree to $5=$ strongly agree). After excluding four filler items (i.e., It's easy for me to 
relax, I enjoy my friends a lot, It's important for me to keep busy, and I don't get upset too easily) and four reverse coded items (Table 4), the short version comprised by four items were derived as shown in Table 3 . The items were reviewed to identify major aspects of optimism. Positive thinking, an optimistic view for future, and self-esteem were found to be three major ideas of optimism. Based on these observations, six items were extracted from the Age and Generations Study. Each item was answered on a sixpoint Likert scale ranging from "strongly disagree" to "strongly agree." The six items are as follows: "I am confident I get the success I deserve in life", "When I try, I really succeed”, "I complete tasks successfully", "Overall, I am satisfied with my life”, "I determine what will happen in my life", and "I am capable of coping with most of my problems." Internal consistency between these six items was measured with Cronbach's alpha, which measured .799, indicating a satisfactory level of internal consistency.

\subsection{Turnover Intention}

Bluedorn (1982) defined "turnover intention" as an employee's conscious and deliberate intention to change jobs or to leave companies. Most previous research used only single item scales to assess turnover intention (Guimaraes, 1997). The single item scale has been criticized because it is impossible to infer construct validity from one single item (Lee, Carswell \& Allen, 2000). 
Table 5

Turnover Intention Scale (Konovsky and Cropanzano, 1991)

1. I intend to look for a job outside of [company name] within the next year

2. I often think about quitting my job at [company name].

3. I intend to remain with this company indefinitely

Konovsky and Cropanzano (1991) used a three-item scale to measure turnover intention. The three items are shown in Table 5. The items were reviewed to identify major aspects of turnover intention. Based on this review, two items were selected to measure turnover intention from Age and Generation Study. Survey items included "It would take a lot to get me to leave my organization" and "Compared to other organizations I know about, I think my organization is a great place to work", with each item answered on a six point strongly disagree-strongly agree Likert-type scale. This constructed scale produced a Cronbach's alpha of .767, indicating a satisfactory level of internal consistency.

\subsection{Career Satisfaction}

Career satisfaction is the extent to which employees are satisfied or content with their career accomplishments (Judge, Cable, Boudreau, \& Bretz, 1995). The career satisfaction scale developed by Greenhaus, Parasuraman, and Wormley (1990) has been used in over 240 studies and has an excellent internal reliability (Hofmans, Dries, \& Pepermans, 2008). This five-item measure was answered on a five-point scale ranging from " 1 = strongly disagree" to $5=$ "Strongly agree". The items are shown in Table 6 . 
Table 6

Career Satisfaction Scale (Greenhaus, Parasuraman, and Wormley, 1990)

1. I am satisfied with the success I have achieved in my career.

2. I am satisfied with the progress I have made toward meeting my overall career goals.

3. I am satisfied with the progress I have made toward meeting my goals for income.

4. I am satisfied with the progress I have made toward meeting my goals for advancement.

5. I am satisfied with the progress I have made toward meeting my goals for the development of new skills

The items were reviewed to identify major aspects of career satisfaction.

Satisfaction with overall career, income, advancement, and the development of new skills appeared as major ideas. Based on this review, five items were selected to measure career satisfaction from Age and Generation Study. Each item was answered on a six-point Likert scale ranging from "strongly disagree" to "strongly agree." The five items are as follows: "I am satisfied with the success I have achieved in my career", "I am satisfied with the progress I have made toward meeting my overall career goals", "I am satisfied with the progress I have made toward meeting my goals for advancement", "I am satisfied with the progress I have made toward meeting my financial objectives", and "I am satisfied with the progress I have made toward my goals for the development of new skills" Internal consistency between these five items was measured with Cronbach's alpha, which measured .918 , indicating a satisfactory level of internal consistency.

\subsection{Work Engagement}

Kahn (1990) identifies that work engagement depends on how much individuals invest themselves on work-related tasks. They tend to feel engaged in the tasks when they 
are able to project themselves on their work cognitively, emotionally, and physically (Kahn, 1990, 1992).

Table 7

Work Engagement Scale (Schaufeli, Bakker, \& Salanova, 2006)

1. At my work, I feel bursting with energy.

2. At my job, I feel strong and vigorous.

3. I am enthusiastic about my job.

4. My job inspires me.

5. When I get up in the morning, I feel like going to work.

6. I feel happy when I am working intensely.

7. I am proud of the work that I do

8. I am immersed in my work

9. I get carried away when I am working

The nine-item Utrecht work engagement scale (Schaufeli, Bakker, \& Salanova, 2006) was used as a guideline in order to select appropriate items from Age and Generation Study. After reviewing the items, work engagement was characterized by energy, enthusiasm, and commitment. Based on these characteristics, three items were selected to measure work engagement. Survey items included "When I get up in the morning, I feel like going to work", "I am enthusiastic about my job, I am immersed in my work", and "I am immersed in my work" with each item answered on a seven point never-always Likert-type scale. This constructed scale produced a Cronbach's alpha of .872 , indicating a satisfactory level of internal consistency. 


\subsection{Organizational Support for Development}

Learning is acquiring knowledge and being ready to apply it for different circumstances in creative ways. A learning orientation has been defined as a concern for and commitment to improving one's capability (Dweck, 1986, 2000; Dweck \& Leggett, 1988). After employment, training and development programs are given in order to improve employees' job skills, expertise, and job performance (Aguinis \& Kraiger, 2009; Arthur, Bennett, Edens, \& Bell, 2003). Companies offer a number of learning opportunities to develop employees' intelligence and knowledge. These include continuing education and training programs, and other opportunities for professional development.

Table 8

Organizational Support for Development Scale (Schein, 1978)

1. My organization has programs and policies that help employees to advance in their functional specialization.

2. My organization provides opportunities for employees to develop their specialized functional skills.

3. My organization has programs and policies that help employees to reach higher managerial levels.

4. My organization has career development programs that help employees develop their specialized functional skills and expertise.

5. My organization provides opportunities for employees to develop their managerial skills.

6. My organization has career development programs that help employees develop their managerial skills. 
To assess the organizational support for development (OSD), the six-item scale (Schein, 1978) worked as a guideline in order to select appropriate items from Age and Generation Study. Through this scale, employees evaluated on a scale from 1 (not at all) to 5 (a very large extent) regarding the extent to which companies provide education and training programs that improve employees' job-related skills. The OSD scale focused on assessing the developments of functional skills and managerial capabilities.

The items were reviewed to identify major ideas of organizational support for development. Based on this through review, three items were selected to assess OSD from Age and Generation Study. Learning opportunities for education training provided by organization were found to be major aspects of OSD. Survey items included "My company promotes the continuous learning and development of all employees", "I am given a real opportunity to improve my skills at this company through education and training programs", and "I am satisfied with the training and development programs available to me", with each item answered on a six point strongly disagree-strongly agree Likert-type scale. This constructed scale produced a Cronbach's alpha of .922, indicating a satisfactory level of internal consistency.

\subsection{Team Effectiveness}

Team Effectiveness requires team members to coordinate their actions (Zaccaro et al, 2001). Recent studies on team/unit-level criteria (Roberson \& Colquitt, 2005; Whitman, Caleo, Carpenter, Horner, \& Bernerth, 2012) have used these four dimensions to classify team effectiveness: attitudinal outcomes (e.g., job satisfaction, commitment), behavioral processes and emergent states (e.g., cooperation, helping, cohesion), (c) 
subjective performance (e.g., subjective ratings), and objective performance (e.g., productivity, actual sales).

Table 9

Team Effectiveness Scale (Sparrowe, Liden, Wayne, and Kraimer, 2001)

1. Quality of work

2. Getting work done efficiently

3. Flexibility in dealing with unexpected changes

4. Overall Performance

Sparrowe, Liden, Wayne, and Kraimer's (2001) used a four-item scale to measure team effectiveness. Through this scale, respondents were evaluated on a scale from 1 (very poor) to 7 (outstanding). The four items are shown in Table 9. The items are carefully reviewed to identify main ideas of team effectiveness. Work efficiency, flexibility, and work quality were found to be three major features of team effectiveness. Using these dimensions as a guide for selecting items relating to Team Effectiveness, four six-point strongly disagree-strongly agree Likert-type survey questions were identified. These items were the following: "The members of my work team make good use of each employee's talent", "The members of my work team use effective communication strategies", "The members of my work team use the resources available in an effective way", and "The members of my work team manage conflict within the team effectively." This constructed scale produced a Cronbach's alpha of .890, indicating a sufficient level of internal consistency. 


\subsection{Pessimism}

Table 10

Beck Hopelessness Scale for Item Review Process

2. I might as well give up because I can't make things better for myself.

4. I can't imagine what my life would be like in 10 years.

7. My future seems dark to me.

9. I just don't get the breaks, and there's no reason to believe I will in the future.

11. All I can see ahead of me is unpleasantness rather than pleasantness.

12. I don't expect get what I really want.

14. Things just won't work out the way I want them to.

16. I never get what I want so it's foolish to want anything.

17. It is very unlikely that I will get any real satisfaction in the future.

18. The future seems vague and uncertain to me

20. There's no use in really trying to get something I want because I probably won't get it.

Table 11

Nine Reverse Code Items from Beck Hopelessness Scale

1. I look forward to the future with hope and enthusiasm.

3. When things are going badly, I am helped by knowing they can't stay that way forever.

5. I have enough time to accomplish the things I most want to do.

6. In the future, I expect to succeed in what concerns me most.

8. I expect to get more of the good things in life than the average person.

10. My past experiences have prepared me well for my future.

13. When I took ahead to the future, I expect I will be happier than I am now.

15. I have great faith in the future

19. I can look forward to more good times than bad times

A person might feel some doubts about his or her own competence as well as current or future prospects. To measure the extent of pessimism, Beck Hopelessness 
Scale (Beck, Weissman, Lester, \& Trexler, 1974) worked as a guideline in order to select appropriate items from Age and Generation Study. The scale consists of twenty true/false items and the Cronbach's alpha of this original scale was calculated as .80 . The nine reverse coded items are more related to positive emotions and are excluded (Table 11). The eleven items were selectively used for consideration. The eleven items are shown in Table 10. The items were reviewed to identify major aspects of pessimism. Passive attitude, negative future perspective, and loss of confidence were found to be three major ideas of pessimism. Based on these observations, I identified six questionnaire items to use as indicators of a pessimistic viewpoint. The six-point Likert scale sttongly disagree, strongly agree items included "Sometimes, I feel depressed", "Sometimes when I fail, I feel worthless", "Sometimes, I do not feel in control of my work", "I am filled with doubts about my competence", "I do not feel in control of my success in my career", and

"There are times when things look pretty bleak and hopeless to me." Internal consistency was measured with Cronbach's alpha, which measured .807, indicating a satisfactory level of internal consistency.

\subsection{Demographic Variables}

Demographic variables like age, gender, education, and work experience were added for analysis to discover how these demographic factors affect the development of informal leadership. Previous research indicated the strong possibility that gender and work experience would affect leadership. Age and education have not generally been found to be important in leadership studies, but since informal leadership relies on personal qualities not necessarily valued or even recognized by appointment to formal 
position within the organization, these variables might be more important for informal than for formal leaders. Each demographic variable has one item to describe itself. An item asking gender identity is straightforward: "Are you male or female?" The age item was "In what year were you born?" For education, the item asked "What is the highest grade you have completed in school?', and presented seven choices covering 'Less than high school' to 'Graduate Degree'. Work experience was identified by the question, "How many years have you have been with [Organization Name], in total" giving respondents the option to enter numbers.

\section{STATISTICAL ANALYSIS}

As a tool for analysis, multiple linear regression analysis is adopted to test Hypothesis 1a to 1e, Hypothesis 2, Hypothesis 3, Hypothesis 4, Hypothesis 6, and Hypothesis 7. In order to compare the means of two independent samples (Hypothesis 5), T-test was used. For Hypothesis 9, concerning the comparison of formal and informal leaders' effects on team effectiveness, partial eta squared was used.

Secondary data were used for this study. After consideration of existing research and relevant theory, items were identified as indicators of the variables under consideration. In cases where scale development was possible, several items relating to the same concept were identified and tested for internal consistency using Cronbach's alpha. A Cronbach's alpha of .7 or more indicates a satisfactory level of internal consistency. 


\subsection{Data}

The analysis is based on the Age and Generations Study. The data were collected from 2007 (November 12th) to 2008 (October 1st) and released at 7th of October at 2013 by Pitt-Catsouphes, Marcie, and Michael Smyer. Data are available through the ICPSR website (http://www.icpsr.umich.edu/icpsrweb/ICPSR/studies/34837). Detailed information about the data set is given in the reference section. The observation unit is the individual with a sample size of 2,195 employees. This survey data set contains employee and employer outcomes which relate to the experiences of work teams in five industry sectors. Retail, pharmaceuticals, finance, health care, and higher education are included in the industry sectors. The study is cross-sectional. Data were collected by paper and pencil interview as well as a web-based survey. The data source contains 582 variables. After a thorough review of 582 items, forty-one variables were selectively used for this study.

\subsection{Variable Descriptions}

Table 12 shows the average values for the eleven variables. Respondents somewhat agree on their own qualifications as informal leaders. The average age of 1,221 respondents is 41.15 years with an average educational level between two year college and the bachelor's degree. On average, respondents have worked for currently employed companies for eight years. Subjects somewhat agree on their companies' levels of learning orientation as 4.5 on a seven-point scale. Employees' turnover intentions are reversely coded. Therefore, the average value of 4.7 on a seven-point scale means that the level of turnover intentions is relatively low among employees. 
Figure 2 depicts the relationship between informal leadership and education degree. As respondents' educational degree levels increase, their informal leadership score increases correspondingly, implying that educational background influences the formation of informal leadership. The reasoning behind Hypothesis 3 seems to be supported by the association shown in this graph. However, Hypothesis 3 needs to go through the step of regression analysis successfully for a final conclusion.

Table 12

Average Value of Eleven Variables

\begin{tabular}{llll}
\hline Variables & $\mathrm{N}$ & Mean & s.d. \\
\hline 1. Informal Leadership & 1,333 & 3.96 & 1.19 \\
2. Age & 1,221 & 41.15 & 12.6 \\
3. Education & 1,239 & 4.63 & 1.6 \\
4. Work Experience & 1,324 & 7.9 & 8.4 \\
5. Learning Orientation & 1,332 & 4.47 & 1.17 \\
6. Team Effectiveness & 1,303 & 4.16 & 1.03 \\
7. Employee Performance & 1,225 & 4.05 & .62 \\
8. Employee Satisfaction & 1,245 & 4.09 & 1.08 \\
9. Pessimism & 1,238 & 2.94 & .91 \\
10. Optimism & 1,239 & 4.76 & .61 \\
10. Work Engagement & 1,224 & 5.03 & 1.42 \\
11. Turnover Intention & 1,218 & 4.7 & 1.07 \\
\hline
\end{tabular}


Figure 2

Association between Informal Leadership and Education Degree Level

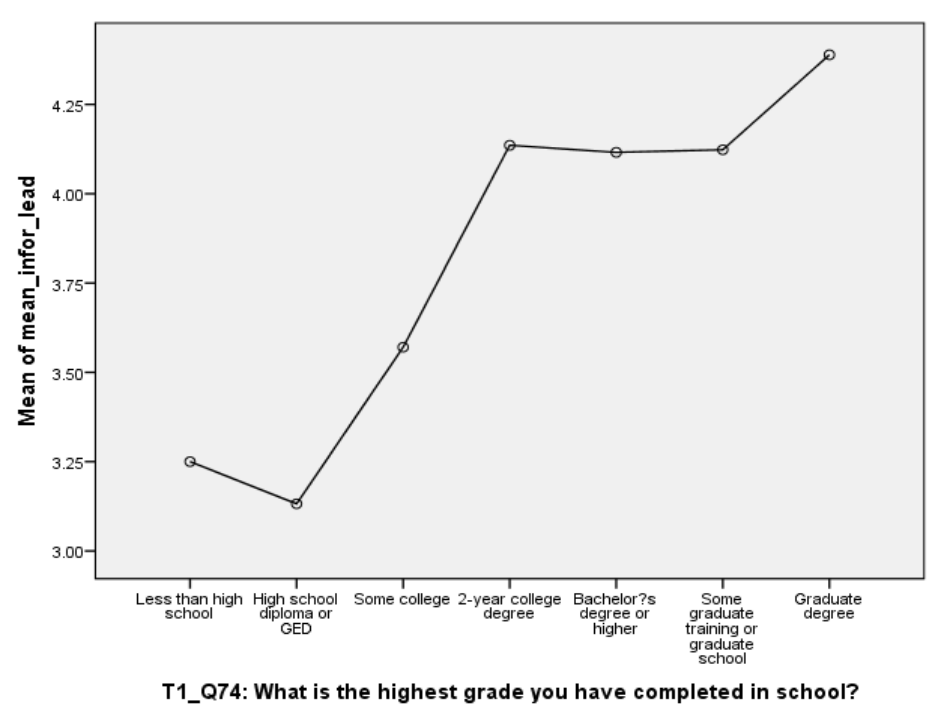

5.3 Correlations between Variables

Correlations are shown in Table 13 and 14. With two different dependent variables, two multiple regression analyses are conducted. First, correlations between eleven variables are obtained in Table 13. Second, correlations between six variables are obtained in Table 14. The asterisks are used as a signal to indicate the statistical significance of results. The significance level less than .01 (or .05) denotes that the correlation is significant and the two variables are linearly associated. Except for the correlations between "education" and "organizational support for development" and between "turnover intention" and "education", all of the estimates turned out to be statistically significant at the .01 (or .05) level in Table 13 . 
It cannot be said that all these associations are meaningful. For example, the relationships between age and education and between age and gender are not based on theoretical assumptions described above.

Table 13

Descriptive Statistics and Correlations for Variables

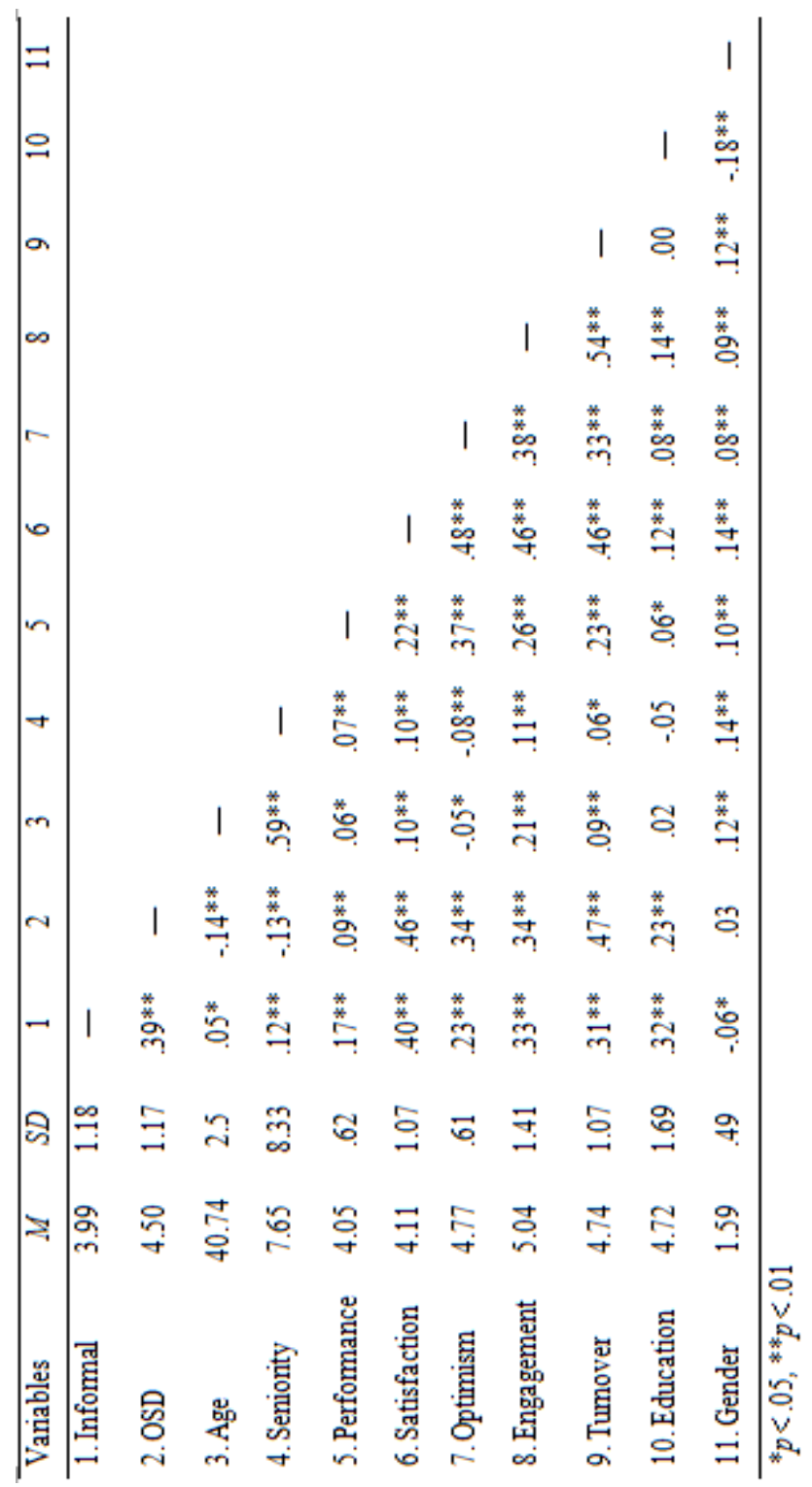


Table 14

Descriptive Statistics and Correlations for Variables

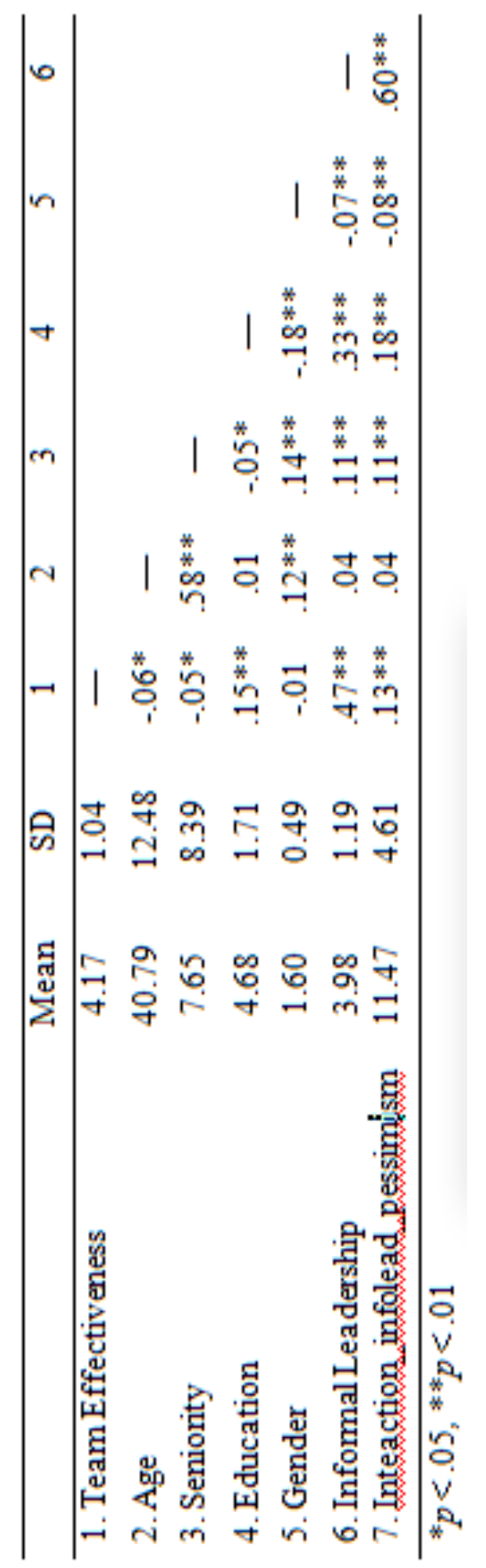




\subsection{Results}

Multiple regression analysis was used to examine the association between informal leadership and different predictors. Tables 16 through 20 summarizes the analysis results. A significance level less than .01 (or .05) denotes that the beta coefficient is significant and the two variables are linearly associated. Except for the coefficients between age and informal leadership and between optimism and informal leadership, all of the relationships hypothesized were statistically significant at the 0.01 (or .05) level in Table 16.

Supporting Hypothesis 1a through 1d, informal leadership was positively related to performance $(\beta=.06, p<.05)($ Table 16$)$, turnover intention $(\beta=.07, p<.05)($ Table 16), career satisfaction $(\beta=.22, p<.01)$ (Table 16$)$, and work engagement $(\beta=.09, p$ <.01) (Table 16). Thus, informal leaders, as expected, score low in turnover intention. In addition, informal leaders perform well, are satisfied with their current career, and are engaged in their work. Hypothesis 2, concerning the relationship between age and informal leadership, was not supported $(p>.01)$ (Table 16). Hypothesis 3, concerning the relationship between education and informal leadership, was supported at the .01 level $(\beta=.22)$ (Table 16). As we hypothesized, having a higher degree contributed to the level of informal leadership. Hypothesis 4, concerning the relationship between work experience and informal leadership, was supported at the .01 level $(\beta=.16)$ (Table 16).

Hypothesis 6, concerning the relationship between organizational support for 
development and informal leadership, was supported at the .01 level $(\beta=.19)$ implying that organizational support for development (OSD) contributes to the formation of informal leadership within the organization (Table 16). Informal leaders are more likely to appear in an organization that provides training and development programs and creates an environment for employees to learn, develop, and improve their skills.

In order to test Hypothesis 5, comparing men vs. women in informal leadership, the T-test was applied (Table $17 \& 18$ ). In order to compare the means of two independent samples (Hypothesis 5), T-test was used. Table 17 and Table 18 describe the statistical results regarding Hypothesis 5. A sample of 750 women had the mean value of $4.1(\sigma=.93)$ in informal leadership. The average score of 500 men was $4.3(\sigma=.94)$. The mean difference between men and women was calculated as .14, indicating that the mean difference between two samples is statistically significant $(p<.01)$. Hypothesis 5 was supported at the .01 level, indicating that men were more likely than women to be informal leaders. The results for Hypothesis 5 are shown in Table 17 and Table 18. Hypothesis 7, concerning the relationship between informal leadership and team effectiveness, was supported at the .01 level $(\beta=.62)$ indicating that informal leadership was positively related to team effectiveness. The regression results of Hypothesis 7 are shown in Table 20. Interaction term (informal leadership $\times$ pessimism) is created for moderator analysis. Hypothesis 8 , concerning the moderating role of pessimism between informal leadership and team effectiveness, demonstrates a negative impact of pessimism, as shown in Table $20(\beta=-.23, p<.01)$. Pessimism is positioned as a moderator between 
informal leadership and team effectiveness. A positive slope between informal leadership and team effectiveness gets smaller as the moderator, pessimism increases. In addition to this, the informal leadership's effect on team effectiveness grows as pessimism increases as indicated. With all of these facts, it appears that the employee's pessimism weakens the relationship between informal leadership and team effectiveness, supporting pessimism's role as moderator. Finally, for Hypothesis 9, concerning the comparison analysis of the effects on the final outcome variable, team effectiveness, between two leadership groups, which are dual leadership (Group 1) and informal leadership (Group 2) partial eta squared was used (Table 21). Partial eta squared is a default measure of effect size reported in factorial ANOVA procedures in SPSS. This analysis shows that leadership group $2\left(h p^{2}=.33\right)$ has a bigger impact on team effectiveness than leadership group $1\left(h p^{2}=.28\right)$. Interestingly, this means that for informal leaders, having a formal supervisory position does not help improve the effect size. Rather, organizational members executing only informal leadership style can have a bigger impact on team effectiveness than those having both power sources, informal and formal leadership. It is logical to think that informal leadership combined with formal power would be more powerful than informal leadership itself. However, this study indicates that informal leadership alone is more effective than dual leadership.

Table 15

Model Summary

\begin{tabular}{cccc}
\hline $\mathrm{R}$ & $\mathrm{R}$ Square & Adjusted R Square & $\mathrm{SE}$ of the Estimate \\
\hline $.558^{\mathrm{a}}$ & 0.31 & 0.30 & 0.98 \\
\hline
\end{tabular}

DV: Informal Leadership 
Table 16

Multiple Regression Analysis

\begin{tabular}{lcccc}
\hline & Coefficient & SE & T-Ratio & P-Value \\
\hline Intercept $\left(\beta_{0}\right)$ & & & & \\
OSD & 0.19 & 0.03 & 6.16 & 0.00 \\
Age & -0.06 & 0.00 & -1.75 & 0.08 \\
Seniority & 0.16 & 0.00 & 5.14 & 0.00 \\
Performance & 0.06 & 0.05 & 2.34 & 0.02 \\
Satisfaction & 0.22 & 0.04 & 6.71 & 0.00 \\
Optimism & -0.02 & 0.06 & -0.70 & 0.49 \\
Engagement & 0.09 & 0.03 & 2.86 & 0.00 \\
Turnover & 0.07 & 0.04 & 2.11 & 0.03 \\
Education & 0.22 & 0.02 & 8.47 & 0.00 \\
Gender & -0.10 & 0.06 & -3.75 & 0.00 \\
\hline
\end{tabular}

DV: Informal Leadership

Table 17

Comparison Between Men and Women (Hypothesis 5)

\begin{tabular}{c|c|c|c|c}
\hline & $\mathrm{N}$ & Mean & Std. Deviation & Std. Error Mean \\
\hline Male & 500 & 4.26 & .94 & .04 \\
Female & 750 & 4.12 & .93 & .03 \\
\hline
\end{tabular}

Table 18

Independent Samples Test (Hypothesis 5)

\begin{tabular}{c|c|c|c|c|c|c}
\hline \multirow{2}{*}{$\mathrm{T}$} & \multicolumn{6}{|c}{ t-test for Equality of Means } \\
\cline { 2 - 7 } & $\mathrm{df}$ & Sig. (2-tailed) & $\begin{array}{c}\text { Mean } \\
\text { Difference }\end{array}$ & $\begin{array}{c}\text { Std. Error } \\
\text { Difference }\end{array}$ & $\begin{array}{c}\text { 95\% Confidence Interval } \\
\text { of the Difference }\end{array}$ \\
\cline { 5 - 7 } & & .01 & .14 & .05 & .03 & .24 \\
\hline 2.505 & 1,248 & & & & Lower & Upper \\
\hline
\end{tabular}

Table 19

Model Summary

\begin{tabular}{cccc}
\hline $\mathrm{R}$ & R Square & Adjusted R Square & SE of the Estimate \\
\hline $.516^{\mathrm{a}}$ & 0.27 & 0.26 & 0.89 \\
\hline
\end{tabular}

DV: Team Effectiveness 
Table 20

Multiple Regression Analysis

\begin{tabular}{lcccc}
\hline & Coefficient & SE & T-Ratio & P-Value \\
\hline Intercept $\left(\beta_{0}\right)$ & & & & \\
Age & -0.03 & 0.00 & -0.98 & 0.33 \\
Seniority & -0.08 & 0.00 & -2.71 & 0.01 \\
Education & -0.01 & 0.02 & -0.40 & 0.69 \\
Gender & 0.03 & 0.05 & 1.18 & 0.24 \\
Informal Leadership & 0.62 & 0.03 & 18.89 & 0.00 \\
Inteaction_infolead_pessimism & -0.23 & 0.01 & -7.13 & 0.00 \\
\hline
\end{tabular}

DV: Team Effectiveness

Table 21

Comparison Analysis of Effect Sizes (Hypothesis 9)

\begin{tabular}{l|c|c|c|c|c|c|c}
\hline & \multirow{2}{*}{$\mathrm{B}$} & \multirow{2}{*}{ Std. Error } & $\mathrm{t}$ & $\mathrm{sig}$ & \multicolumn{2}{|c|}{$95 \%$ Confidence Interval } & \multirow{2}{*}{$\begin{array}{c}\text { Partial Eta } \\
\text { Squared }\end{array}$} \\
\cline { 5 - 7 } & & & & $\begin{array}{c}\text { Lower } \\
\text { Bound }\end{array}$ & $\begin{array}{c}\text { Upper } \\
\text { Bound }\end{array}$ & \\
\hline Group 1 & .63 & .04 & 16.36 & .00 & .55 & .70 & .28 \\
Group 2 & .63 & .03 & 25.18 & .00 & .58 & .68 & .33 \\
\hline
\end{tabular}

\section{DISCUSSION AND CONCLUSION}

Even though informal leaders do not possess formal authority, they influence other members and are respected as leaders by them. Informal leaders execute influence differently from formal leaders. Without formally assigned supervisory power, the influence of informal leaders is based on personal ability and personality. This study focused on the referent power of informal leaders. Referent power means a capability to influence not by official authority, but by example. Which factors make followers take informal leaders as their role models? Followers observe and imitate the behaviors of their leaders. Four barometers, i.e., performance, turnover intention, career satisfaction, 
and work engagement, were chosen to represent the personal traits of informal leaders. As theorized, there were statistically significant relationships between these four indicators and informal leadership. Informal leaders scored high in performance, high in career satisfaction, high in work engagement, and low in turnover intention. Satisfied, engaged, superior performers were likely to exert a great influence over others.

Do demographic variables contribute to the formation of informal leadership? Four demographic variables, i.e., age, educational background, work experience, and gender, were selected for analysis. Therefore, four hypothetical relationships between these demographic variables and informal leadership were created. Repeating the results from previous research, age did not have a significant role forming informal leadership. Education provides people opportunities to acquire specialized knowledge or expertise to be more competent at resolving workplace problems. Previous researchers have not looked into the relationship between education level and informal leadership. Meaningfully, this study found a positive relationship between educational level and informal leadership. Seniority has become a main factor predicting leadership in prior research. It has been understood that the longer an employee works, the more opportunities there are for professional development. Through these opportunities, employees should be able to improve work related skills. This should lead employees to grow in informal leadership. In this study, work experience was a significant factor affecting the formation of informal leadership. Comparing informal leadership of women and men, this study tested whether women score higher than men in informal leadership. Informal leadership was more noteworthy in men than women, suggesting that women 
may have difficulty overcoming gender-related challenges even though they genuinely possess the personal characteristics of informal leaders. Consistent with results from previous quantitative studies on gender differences, the mean value of men (4.3 out of 5) is slightly higher than that of women (4.1 out of 5). Since this study did not provide clear evidence for this result, future research should consider why informal leadership characteristics are less effective for women than men.

This study tested how organizational support for development (OSD) influences the level of informal leadership. The company's support for development is its willingness to offer employees various learning opportunities for the purpose of expanding and improving their knowledge base. An organization provides a set of learning and training opportunities for employees to hone their work related skills. These learning and training opportunities can develop employees' abilities as informal leaders. The company's support for development fostered a motivating environment for informal leaders. In promoting personal growth, the company's support for development contributed to developing informal leadership capabilities among employees.

The association between informal leadership and team effectiveness was examined. This study found that informal leadership contributed to team effectiveness. The pessimism of employees was added to this relationship and tested as a moderator weakening the association. The employee's negative feeling weakened the relationship between informal leadership and team effectiveness, supporting the role of pessimism as a moderator. 
Some employees hold both formal and informal leadership, while others hold only informal leadership. Two leadership groups (Leadership Group 1 and Leadership Group 2) were created as appeared in Figure 1. Different levels of influence as informal leaders interact with their possession or non-possession of formal power. The strengths of these two leadership groups in affecting team effectiveness were examined and compared. Leaders nurture opportunities for members to participate more actively, to be more cooperative, to have less workplace conflict, and to be more effective. Informal leaders can have an effect on firm and team performance. Initially, it seemed that informal leaders would be influential when designated as formal leaders. Two leadership groups (Leadership Groups 1 and 2) were created as appeared in Figure 1. Different levels of influence as informal leaders interact with formal power. Employees included in Leadership Group 1 hold both formal and informal leadership. Employees from Leadership Group 2 display only informal leadership. The strengths of these two leadership groups in affecting team effectiveness were examined and compared. It seemed reasonable to think that formal power with informal leadership would be more influential than informal power by itself. Team effectiveness was adopted as a final outcome variable in this study. Unexpectedly, the results indicated that formal supervisory power combined with informal power did not contribute to team effectiveness. Rather, it decreased the positive effect of informal leadership on team effectiveness. The leadership group possessing only informal power sources reported more influence on team effectiveness. It will be interesting to investigate why formal power with informal power has a smaller effect than informal power alone. Perhaps formal power is even less influential than informal power. Further research to pick out 
formal power by itself and to examine its single effect on team effectiveness could not be made in this study. Through future research, we will be able to examine how formal power functions to decrease team effectiveness and how it interacts with informal power sources. The contradictory aspects of formal power are reserved for a future study.

Most leadership research has focused on the traditional vertical type of leadership. Recently, leadership research started to investigate the role of followers. There is no single best type of leadership that can work in every type of situation. In order to reach a desirable stage of leadership, leaders have reciprocal relationships with followers reacting to various situations such as industry type, culture, level of economic advancement, and type of task. From time to time, formal leaders need to be flexible and to recognize the leadership qualities of followers. With this delegation process, followers can take significant roles in a dynamic context. Concentrating on formal power over followers, leaders may ignore the desirable aspects of informal leadership, affecting organizational outcome variables negatively. This study is meaningful in that it shows the importance of informal leadership and power delegation, and should stimulate future research on that perspective. Additionally, systematic analysis on how informal and formal leadership work differently and interact with each other within organizations can make theoretical and practical contributions in leadership research.

Another possible topic for future research is the potentially negative aspect of informal leadership. In certain situations, informal leadership can be more influential than formal leadership. If informal leadership works positively, it can complement formal 
leadership. However, if the purpose of informal leadership is to interrupt formal leadership processes, organizations may end up falling into the dysfunction.

Eastern cultures value seniority. In Eastern cultures laying much emphasis on paternalistic leadership and Confucian values, experience and seniority are admired (Cheng et al., 2004). In addition, gender roles are varied in different cultures. The sample used for this study is based in the United States. If we include subjects from other cultures in this study, the results are likely to be changed. The analysis results related to this comparative study may be affected by cultural contexts. The age related research question, which is the second (age) hypothesis, appeared not to be statistically significant, but results might be different when cultural factors are added to the model. Therefore, examining the relationships between informal leadership and the variables affected by culture can be an agenda for future research.

The data are self-reported, mono-method, and secondary data. Secondary data containing 582 variables allowed us to analyze data from various angles. However, all of the variables came from the individual (employee) level, even though the subjects assessed team effectiveness and organizational support for development from team or company levels. There are limitations in creating new scales instead of using currently existing scales. To make up the weaknesses, several procedures were adopted for this study. First, for each construct, one popular existing scale was chosen. The selected scale was examined carefully. Based on this observation, a group of items were sorted from the Age and Generations Study and were combined as initial scales. Initially selected measures were reviewed by the advisory committee for face validity. After this review, 
irrelevant items were eliminated. For all scales, Cronbach's alpha was calculated to check internal consistency between items. The estimate of .7 indicates an acceptable level of internal consistency (George \& Mallery, 2003). Every scale exceeded this criteria.

Even though secondary data is not free from genuine weaknesses and limitations in creating scales, utilizing it has several advantages compared to making use of primary data collected by survey. First, it saves time without the need for data collection, data coding, and data entry. Second, depending on a huge sample size and a large amount of money invested to develop the dataset and reliable statistical methods, publicized data leads us to have theoretically and statistically meaningful relations between variables. Third, publicly available data allow for confirmatory analysis and further testing. With a plethora of leadership research that has emphasized the traditional formal leadership perspective, this study attempted to examine the qualities that contributed to developing informal (i.e., shared or distributed) leadership and its effect on team effectiveness. I hope this study stimulate further research related to informal leadership. 


\section{LIST OF REFERENCES}

Aguinis, H., \& Kraiger, K. (2009). Benefits of training and development for individuals and teams, organizations, and society. Annual Review of Psychology, 60, 451-474.

Akhter, S., Ghayas, S., \& Adill, A. (2013). Self-efficacy and optimism as predictors of organizational commitment among bank employees. International Journal of Research Studies in Psychology, 2, 33-42.

Al-Hussami M. (2008). A Study of nurses' job satisfaction: The relationship to organizational commitment, perceived organizational support, transactional leadership, transformational leadership, and level of education. European Journal of Scientific Research, 22, 286-295.

Allen, D.G., Shore, L.M., \& Griffeth, R.W (2003). The role of POS in the voluntary turnover process. Journal of Management, 29, 99-118.

Andersson, L. M., \& Bateman, T. S. (1997). Cynicism in the workplace: Some causes and effects. Journal of Organizational Behavior, 18, 449-46.

Antonakis, J., Avolio, B. J., \& Sivasubramaniam, N. (2003). Context and leadership, An examination of the nine-factor full-range leadership theory using the multifactor leadership questionnaire MLQ Form 5X. The Leadership Quarterly, 14, 261-295.

Archer, J. (1996). Sex differences in social behavior: Are the social role and evolutionary explanations compatible? American Psychologist, 51, 909-917.

Arthur, W., Jr., Bennett, W. J., Edens, P., \& Bell, S. T. (2003). Effectiveness of training in organizations: A meta-analysis of design and evaluation features. Journal of Applied Psychology, 88, 234-245.

Ashkanasy, N. M., \& Tse, B. (2000). Transformational leadership as management of emotions. A conceptual review. In N. Ashkanasy, C. Hartel, \& W. Zerbe (Eds.), Emotions in the workplace: Development in the study of the managed heart. Wesport, CT: Quorum Books.

Avolio, B. J., Gardner, W. L., Walumbwa, F. O., Luthans, F., \& May, D. R. (2004). Unlocking the mask: A look at the process by which authentic leaders impact follower attitudes and behaviors. The Leadership Quarterly, 15, 801-823.

Avolio, B. J., \& Gardner, W. L. (2005). Authentic leadership development: Getting to the root of positive forms of leadership. The Leadership Quarterly, 16, 315-338. 
Avolio, B.J., \& Gibbons, T.C. (1988). Developing transformational leaders: A life span approach. In J.A. Conger \& R.N. Kanungo (Eds.), Charismatic leadership: The elusive factor in organizational effectiveness (pp. 276-307). San Francisco: Jossey-Bass.

Avolio, B. J., Jung, D. I., Murry, W., \& Sivasubramaniam, N. (1996). Building highly developed teams: Focusing on shared leadership processes, efficacy, trust and performance. Advances in Interdisciplinary Studies on Work Teams, 3, 173-209.

Avolio, B., Walumbwa, F., \& Weber, T. (2009). Leadership: Current theories, research, and future directions. Annual Review of Psychology, 60, 421-449.

Bakker, A. B. (2009). Building engagement in the workplace. In C. Cooper \& R. Burke (Eds.), The peak performing organization (pp. 50-72). London: Routledge.

Balkundi, P., \& Kilduff, M. (2006). The ties that lead: A social network approach to leadership. The Leadership Quarterly, 16, 941-961.

Bandura, A. (1977). Social learning theory. Englewood Cliffs, NJ: Prentice-Hall.

Bandura, A. (1986). Social foundations of thought and action: A social cognitive theory. Englewood Cliffs, NJ: Prentice Hall.

Barbuto, J. E., Fritz, S. M., Matkin, G. S., \& Marx, D. B. (2007). Effects of gender, education, and age upon leader's use of influence tactics and full range leadership behaviors. Sex Roles, 56, 71-83.

Barrick, M. R., \& Mount, M. K. (1991). The Big Five personality dimensions and job performance: A meta-analysis. Personnel Psychology, 44, 1-26.

Barry, D. (1991). Managing the bossless team: Lessons in distributed leadership. Organizational Dynamics, 20, 31-47.

Barsade, S. G. (2002). The ripple effect: Emotional contagion and its influence on group behavior. Administrative Science Quarterly, 47, 644-675.

Bass, B. M. (1990). Bass and Stogdill's handbook of leadership: Theory, research, and managerial applications (3rd ed.). New York: Free Press.

Bass, B. M., \& Bass, R. (2008). The Bass handbook of leadership. New York: Free Press.

Bass, B. M., \& Steidlmeier, P. (1999). Ethics, character, and authentic transformational leadership behavior. The Leadership Quarterly, 10, 181-217.

Beal, C. R. (1994). Boys and girls: The development of gender roles. New York: McGraw-Hill. 
Beck, A. T., Weissman, A., Lester, D. \& Trexler, L. (1974). The measurement of pessimism: The hopelessness scale. Journal of Consulting and Clinical Psychology, 42, $861-865$.

Bjornstad, R. (2006). Learned helplessness, pessimistic workers, and multiple unemployment equilibria. The Journal of Socio-Economics, 35, 458-475.

Bluedorn, A. D. (1982). A unified model of turnover from organizations. Human Relations, 35, 135-153.

Bono, J. E., \& Judge, T. A. (2004). Personality and transformational and transactional leadership: A meta-analysis. Journal of Applied Psychology, 89, 901-910.

Book, E. W. (2000). Why the best man for the job is a woman. New York: Harper Collins.

Borman W. C,, Hanson M. A., Oppler S. H., Pulakos, E. D., \& White, L. A. (1993). Role of early supervisory experience in supervisor performance. Journal of Applied Psychology, 78, 443-449.

Bowen, C. E., Noack, C. M. G., \& Staudinger, U. M. (2010). Aging in the work context. In K. W. Schaie \& S. L. Willis (Eds.), Handbook of the psychology of aging (7th ed., pp. 263-287). San Diego, CA: Elsevier Academic Press.

Bower, G. H. (1981). Mood and memory. American Psychologist, 36, 129-148.

Bowers, D. G., \& Seashore, S. E. (1966). Predicting organizational effectiveness with a four factor theory of leadership. Administrative Science Quarterly, 11, 238-263.

Brass, D. J. (1992). Power in organizations: A social network perspective. In G. Moore, \& J. A. Whitt (Eds.), Research in politics and society (pp. 295-323). Greenwich, CT: JAI Press.

Brass, D.J. (1995). A social network perspective on human resources management. Research in Personnel and Human Resources Management, 13, 39-79.

Bressler, M. E. (2006). Relationship between hope, optimism, organizational commitment, and turnover intention among United States Army Reserve soldiers. Unpublished Master's thesis, University Of Houston-Clear Lake, USA.

Brown, M. E., Treviño, L. K., \& Harrison, D. A. (2005). Ethical leadership: A social learning perspective for construct development and testing. Organizational Behavior and Human Decision Processes, 97, 117-134. 
Bussey, K., \& Bandura, A. (1999). Social cognitive theory of gender development and differentiation. Psychological Review, 106, 676-713.

Carson, J. B., Tesluk, P. E., \& Marrone, J. A. (2007). Shared leadership in teams: An investigation of antecedent conditions and performance. Academy of Management Journal, 50, 1217-1234.

Carver, C., \& Scheier, M. (2002). Optimism. In C. R. Synder \& J. Shane (Eds.), Handbook of positive psychology. New York: Oxford.

Chan, K., \& Drasgow, F. (2001). Toward a theory of individual differences and leadership: Understanding the motivation to lead. Journal of Applied Psychology, 86, 481-498.

Cheng, B. S., Chou, L. F., Huang, M. P., Wu, T. Y. \& Farh, J. L. (2004) Paternalistic leadership and subordinate responses: Establishing a leadership model in Chinese organizations. Asian Journal of Social Psychology, 7, 89-117.

Cohen, S. G. and Bailey, D. E. (1997). What makes teams work: Group effectiveness research from the shop floor to the executive suite. Journal of Management, 23, 239-290.

Cole, M. S., Bruch, H., \& Shamir, B. (2009). Social distance as a moderator of the effects of transformational leadership - Both neutralizer and enhancer. Human Relations, 62, 1697-1733.

Conger, J. A., \& Kanungo, R. N. (1998). Charismatic leadership in organizations. Thousand Oaks, CA: Sage.

Conger, J. A., \& Pearce, C. L. (2003). A landscape of opportunities: Future research in shared leadership. In C. L. Pearce \& J. A. Conger (Eds.), Shared leadership (pp. 285-303). Thousand Oaks, CA: Sage.

Connelly, M. S., Gaddis, B., \& Helton-Fauth, W. (2002). A closer look at the role of emotions in transformational and charismatic leadership. In B. J. Avolio, \& F. J. Yammarino (Eds.), Transformational and charismatic leadership: The road ahead . New York, NY: Elsevier Science.

Dachler, H. P. (1992). Management and leadership as relational phenomena. In M. Von Cranach, W. Doise, \& G. Mugny (Eds.), Social representations and the social bases of knowledge (pp. 169-178). Bern, Switzerland: Haupt.

Day, D., Gronn, P., \& Salas, E. (2004). Leadership capacity in teams. The Leadership Quarterly, 15, 857-880. 
Day, D., Gronn, P., \& Salas, E. (2006). Leadership in team-based organizations: On the threshold of a new era. The Leadership Quarterly, 17, 211-216.

De Hoogh, A. H. B., \& Den Hartog, D. N. (2008). Ethical and despotic leadership, relationships with leader's social responsibility, top management team effectiveness and subordinates' optimism: A multi-method study. The Leadership Quarterly, 19, 297-311.

Digman, J. M. (1990). Personality structure: Emergence of the five-factor model. In M. R. Rosenzweig, \& L. W. Porter (Eds.), Annual Review of Psychology, vol. 41 (pp. $417-$ 440). Palo Alto, CA: Annual Reviews.

Dirks, K. T., \& Ferrin, D. L. (2002). Trust in leadership: Meta-Analytic findings and implications for research and practice. Journal of Applied Psychology, 87, 611-628.

Dolfi, J. and Andrews, E. J. (2007). The subliminal characteristics of project managers: An exploratory study of optimism overcoming challenge in the project management work environment. International Journal of Project Management, 25, 674682.

Doloff, P. G. (1999). Beyond the organization chart. Across the Board, 36, 43-47.

Drath, W. H. (2001). The deep blue sea: Rethinking the source of leadership. San Francisco: Jossey-Bass.

Druskat, V. (1994). Gender and leadership style: Transformational and transactional leadership in the Roman Catholic Church. The Leadership Quarterly, 5, 99-119.

Druskat, V. U., \& Wheeler, J. V. (2003). Managing from the boundary: The effective leadership of self-managing work teams. Academy of Management Journal, 46, 435-457.

Dubinsky, A. J., Yammarino, F. J., Jolson, M. A., \& Spangler, W. D. (1995).

Transformational leadership: An initial investigation in sales management. Journal of Personal Selling and Sales Management, 15, 17-29.

Dweck, C. S. (1986). Motivational processes affecting learning. American Psychologist, 41, 1040-1048.

Dweck, C. S. (2000). Self-theories: Their role in motivation, personality, and development. Philadelphia: Psychological Press.

Dweck, C. S., \& Leggett, E. L. (1988). A social-cognitive approach to motivation and personality. Psychological Review, 95, 256-273. 
Eagly, A. H. (1987). Sex differences in social behavior: A social-role interpretation. Hillsdale, NJ: Erlbaum.

Eagly, A. H., \& Carli, L. (2007). Through the labyrinth: The truth about how women become leaders. Boston, MA: Harvard Business School Press.

Eagly, A.H.,\& Johnson, B.T. (1990). Gender and leadership style: A meta-analysis. Psychological Bulletin, 108, 233-256.

Eagly, A. H., \& Karau, S. J. (1991). Gender and the emergence of leaders: A metaanalysis. Journal of Personality and Social Psychology, 60, 685-710.

Eagly, A. H., \& Karau, S. J. (2002). Role congruity theory of prejudice toward female leaders. Psychological Review, 109, 573-598.

Eagly, A. H., Karau, S. J., \& Makhijani, M. G. (1995). Gender and the effectiveness of leaders: A meta-analysis. Psychological Bulletin, 117, 125-145.

Eagly, A. H., \& Wood, W. (1982). Inferred sex differences in status as a determinant of gender stereotypes about social influence. Journal of Personality and Social Psychology, 43, 915-928.

Eagly, A. H., \& Wood, W. (1999). The origins of sex differences in human behavior: Evolved dispositions versus social roles. American Psychologist, 54, 408-423.

Edmondson, A. (1999). Psychological safety and learning behavior in work teams. Administrative Science Quarterly, 44, 350-383.

Eisenberger, R., Cummings, J., Armeli, S., \& Lynch, P. (1997). Perceived organizational support, discretionary treatment, and job satisfaction. Journal of Applied Psychology, 82, 812- 820 .

Eisenberger, R., Huntington, R., Hutchison, S., \& Sowa, D. (1986). Perceived organizational support. Journal of Applied Psychology, 71, 500-507.

Eisenberger, R., Stinglhamber, F., Vandenberghe, C., Sucharski, I. L., \& Rhoades, L. (2002). Perceived supervisor support: Contributions to perceived organizational support and employee retention. Journal of Applied Psychology, 87, 565-573.

Eisenhardt, K. M. \& Tabrizi, B. N. (1995). Accelerating adaptive processes: Product innovation in the global computer industry. Administrative Science Quarterly, 4, 84-110. 
Ensley, M. D., Hmieleski, K. M., \& Pearce, C. L. (2006). The importance of vertical and shared leadership within new venture top management teams: Implications for the performance of startups. The Leadership Quarterly, 17, 217-231.

Ensley, M. D., A.W. Pearson, \& C.L. Pearce (2003). Shared leadership, top management team process and new venture performance: A theoretical model and research agenda. Human Resource Management Review, 13, 329-346.

Epitropaki, O., \& Martin, R. (2004). Implicit leadership theories in applied settings: Factor structure, generalizability, and stability over time. Journal of Applied Psychology, 89, 293-310.

Erez, M., \& Arad, R. (1986). Participative goal-setting: Social, motivational, and cognitive factors. Journal of Applied Psychology, 71, 591-597.

Fairholm, G. W. (1998). Perspectives on leadership: From the science of management to its spiritual heart. Westport, CT: Quorum Books.

Follett, M. P. (1924). Creative experience. New York: Logmans Green.

Forgas, J. P., Bower, G. H., \& Moylan, S. J. (1990). Praise or blame? Affective influences on attributions for achievement. Journal of Personality and Social Psychology, $59,809-818$

Fredrickson, B. L. (2001). The role of positive emotions in positive psychology: The broaden-and-build theory of positive emotions. American Psychologist, 56, 218-226.

French, J. R. P., \& Raven, B. (1959). The bases of social power. In D. Cartwright (Ed.), Studies of social power (pp. 150-167). Ann Arbor, MI: University of Michigan, Institute for Social Research.

Friedrich, T. L., Vessey, W. B., Schuelke, M. J., Ruark, G. A., \& Mumford, M. D. (2009). A framework for understanding collective leadership: The selective utilization of leader and team expertise within networks. The Leadership Quarterly, 20, 933-958.

Gallagher, S. (2014) Yes, Master's: A graduate degree's moment in the age of higher education innovation, The New England Journal of Higher Education. 5 August 2014.

Gardner, W. L., \& Schermerhorn Jr., J. R. (2004). Unleashing individual potential: Performance gains through positive organizational behavior and authentic leadership. Organizational Dynamics, 33, 270-281.

George, J. M. (1991). State or trait: Effects of positive mood on prosocial behaviors at work. Journal of Applied Psychology, 76, 299-307. 
George, J.M. (1995). Leader positive mood and group performance: The case of customer service. Journal of Applied Social Psychology, 25, 778-794.

George, J. M. (2000). Emotions and leadership: The role of emotional intelligence. Human Relations, 53, 1027-1055.

George, J. M., \& Bettenhausen, K. (1990). Understanding prosocial behavior, sales performance, and turnover: A group-level analysis in a service context. Journal of Applied Psychology, 75, 698-709.

George, D., \& Mallery, P. (2003). SPSS for Windows step by step: A simple guide and reference. 11.0 update (4th ed.). Boston: Allyn \& Bacon.

Gibb C. A. (Ed.). (1954). Leadership (Vol. 2). Reading, MA: Addison-Wesley.

Gilbreth, F. B., \& Gilbreth, L. M. (1924). Classifying the elements of work. Management and Administration, 8, 151-154.

Goldsmith, R. E., \& Matherly, T. A. (1988). Creativity and self-esteem: A multiple operationalization validity study. Journal of Psychology, 122, 47-56.

Gough, H. G. (1990). Testing for leadership with the California Psychological Inventory. In K. E. Clark \& M. B. Clark (Eds.), Measures of leadership (pp. 355-379). West Orange, NJ: Leadership Library of America.

Greenhaus, J., Parasuraman, S., and Wormley, W. (1990). Effects of race on organizational experiences, job performance evaluations, and career outcomes. The Academy of Management Journal, 33, 64-86.

Greenleaf, R. K. (1977). Servant leadership: A journey into the nature of legitimate power and greatness. New York: Paulist Press

Gronn, P. (1999a). Substituting for leadership: The neglected role of the leadership couple, The Leadership Quarterly, 10, 41-62.

Gronn, P. (1999b). Systems of distributed leadership in organisations, paper presented to the Organisation Theory SIG at the annual meeting of the American Educational Research Association, Montreal.

Gronn, P. (2000). Distributed properties: A new architecture for leadership. Educational Management and Administration, 28, 317-338.

Gronn, P. (2002). Distributed leadership as a unit of analysis. The Leadership Quarterly, $13,423-451$. 
Gronn, P. (2004). In G. Goethals, G. Sorenson, \& J. MacGregor Burns (Eds.), Distribution of leadership. Encyclopedia of leadership, Vol. 1. (pp. 351-355). Thousand Oaks, California: Sage.

Grossman, R. J. (2000). Emotions at work. Health Forum Journal, 43, 18-22.

Guimaraes, T. (1997). Assessing employee turnover intentions before/after TQM:

International Journal of Quality \& Reliability Management, 14, 46-63.

Guzzo, R. A., \& Dickson, M. W. (1996). Teams in organizations: Recent research on performance and effectiveness. Annual Review of Psychology, 47, 307-338.

Hackman, J. R., \& Walton, R. E. (1986). Leading groups in organizations. In P. S. Goodman \& Associates (Eds.), Designing effective work groups (pp. 72-119). San Francisco: Jossey-Bass.

Hanneman, R. A., \& Riddle, M. (2005). Introduction to social network methods. Riverside, CA: University of California, Riverside.

Harter, J. K., Schmidt, F. L., \& Hayes, T. L. (2002). Business-unit-level relationship between employee satisfaction, employee engagement, and business outcomes: a metaanalysis. The Journal of Applied Psychology, 87, 268-279.

Hiller, N., Day, D., \& Vance, R. (2006). Collective enactment of leadership roles and team effectiveness: A field study. The Leadership Quarterly, 17, 387-397.

Hoch, J. E. (2007). Verteilte Führung in virtuellen Teams: Zum Einfluss struktureller, interaktionaler und teambasierter Führungstechniken auf den Teamerfolg [Distributed leadership in virtual teams: The impact of structural, interactive, and team-based leadership on team success]. Germany: University of Kiel, Unpublished doctorial dissertation.

Hoch, J. E., Pearce, C. L., \& Welzel, L. (2010). Is the most effective team leadership shared? The impact of shared leadership, age diversity, and coordination on team performance. Journal of Personnel Psychology, 9, 105-116.

Hochwarter, W. A., Kacmar, C., Perrewe, P. L., \& Johnson, D. (2003). Perceived organizational support as a mediator of the relationship between politics perceptions and work outcomes. Journal of Vocational Behavior, 63, 438-456.

Hofmans, J., Dries, N. and Pepermans, R. (2008). The career satisfaction scale: Response bias among men and women. Journal of Vocational Behavior, 73, 397-403. 
Hollander, E. P., \& Julian, J. W. (1969). Contemporary trends in the analysis of leadership processes. Psychological Bulletin, 71, 387-397.

Howell, J., Shea, C., \& Higgins, C. (2005). Champions of product innovations: Defining, developing, and validating a measure of champion behavior. Journal of Business Venturing, 20, 641-661.

Hoyt, C. L. (2010). Women, men, and leadership: Exploring the gender gap at the top. Social and Personality Psychology Compass, 4, 484-498.

Hunt, J. G. (2004). What is leadership? In J. Antonakis, A. T. Cianciolo, \& R. J. Sternberg (Eds.), The nature of leadership (pp. 19-47). Thousand Oaks, CA: Sage.

Hunt, J. G., \& Dodge, G. E. (2000). Leadership déjà vu all over again. The Leadership Quarterly, 11, 435-458.

Hunt, J. G., \& Ropo, A. (1997). Leadership and faculty motivation. In J. L. Bess (Ed.), Teaching well and liking it: Motivating faculty to teach effectively (pp. 219-247). Baltimore, MD: Johns Hopkins.

Hurtz, G. M., \& Williams, K. J. (2009). Attitudinal and motivational antecedents of participation in voluntary employee development activities. Journal of Applied Psychology, 94, 635-653.

Isen, A. M., \& Baron, R. A. (1991). Positive affect as a factor in organizational behavior. In B.M. Staw and L.L. Cummings (Eds), Research in organizational behavior, Vol. 13. Greenwich, CT: JAI Press, 1991, pp. 1-54.

Isen, A. M.. Johnson, M. M. S., Mertz, E., \& Robinson, G. F. (1985). The influence of positive affect on the unusualness of word associations. Journal of Personality and Social Psychology, 48, 1-14.

Isen, A. M., Danbman, K. A., \& Nowicki, G. P. (1987). Positive affect facilitates creative problem solving. Journal of Personality and Social Psychology, 52, 1122-1131.

Ito, J. K., \& Brotheridge, C. M. (2005). Does supporting employees' career adaptability lead to commitment, turnover, or both? Human Resource Management, 44, 5-19.

Javidan, M., Dorfman, P. W., de Luque, M. S., \& House, R. J. (2006). In the eyes of the beholder: Cross-cultural lessons in leadership from Project GLOBE. Academy of Management Perspectives, 20, 67-90.

Jensen, L., \& Slack, T. (2003). Underemployment in America: Measurement and evidence. American Journal of Community Psychology, 32, 21-31. 
Judge, T. A., \& Bono, J. E. (2000). Five-factor model of personality and transformational leadership. Journal of Applied Psychology, 85, 751-765.

Judge, T. A., Cable, D. M., Boudreau, J. W., \& Bretz, R. D. (1995). An empirical investigation of the predictors of executive career success. Personnel Psychology, 48, 485-519.

Judge, T. A., \& Piccolo, R. F. (2004). Transformational and transactional leadership: A meta-analytic test of their relative validity. Journal of Applied Psychology, 89, 755-768.

Kahn, W. A. (1990). Psychological conditions of personal engagement and disengagement at work. Academy of Management Journal, 33, 692-724.

Kahn, W. A. (1992). To be fully there: Psychological presence at work. Human Relations, 45, 321-349.

Kanfer, R., \& Ackerman, P. L. (2004). Aging, adult development, and work motivation. Academy of Management Review, 29, 440-458.

Katz, R., \& Kahn, R. L. (1978). The social psychology of organisations. New York, NY: Wiley.

Katzenbach, J. R. and Smith, D. K. (1993). The wisdom of teams. Boston: Harvard Business School Press.

Kaufmann, G. (2003). Expanding the mood-creativity equation. Creativity Research Journal, 15, 131-135.

Keltner, D. P., Ellsworth, C., \& Edwards, K. (1993). Beyond simple pessimism: Effects of sadness and anger on social perception. Journal of Personality and Social Psychology, $64,740-752$.

Kent, R. L., \& Moss, S. E. (1994). Effects of sex and gender role on leader emergence. Academy of Management Journal, 37, 1335-1346.

Klein, K. J., Ziegert, J. C., Knight, A. P., \& Xiao, Y. (2006). Dynamic delegation: Shared, hierarchical, and deindividualized leadership in extreme action teams. Administrative Science Quarterly, 51, 590-621.

Konovsky, M. A., \& Cropanzano, R. (1991). The perceived fairness of employee drug testing as a predictor of employee attitudes and job performance. Journal of Applied Psychology, 76, 698-707. 
Kouzes, J. M., \& Posner, B. Z. (1995). The leadership challenge: How to keep getting extraordinary things done in organizations. California: Jossey-Bass.

Kozlowski, S. W. J., \& Bell, B. S. (2003). Work groups and teams in organizations. In W. C. Borman \& D. R. Ilgen (Eds.), Comprehensive handbook of psychology: Industrial and organizational psychology, vol. 12: 333-375. New York: Wiley.

Kozlowski, S. W. J., Gully, S. M., Salas, E., \& Cannon-Bowers, J. A. (1996). Team leadership and development: Theory principles, and guidelines for training leaders and teams. In M. Beyerlein, D. Johnson \& S. Beyerlein (Eds.), Advances in interdisciplinary studies of work teams: Team leadership (Vol. 3), 251-289.

Kraimer, M. L., \& Wayne, S. J. (2004). An examination of perceived organizational support as a multidimensional construct in the context of an expatriate assignment. Journal of Management, 30, 209-237.

Lawler, E. (1986). High-involvement management: Participative strategies for improving organizational performance. San Francisco: Jossey-Bass.

Lee, S. (2004). Seniority as an employment norm: The case of layoffs and promotion in the US employment relationship. Socio-Economic Review, 2, 65-86.

Lee, C.H. and Bruvold, N.T. (2003) Creating value for employees: Investment in employee development. International Journal of Human Resource Management, 14: 9811000 .

Lee, K., Carswell J. \& Allen, N. (2000). A meta-analytic review of occupational commitment: Relations with person and work-related variables, Journal of Applied Psychology, 85: 799-811.

Leroy, H., Palanski, M. E., \& Simons, T. (2012). Authentic leadership and behavioral integrity as drivers of follower commitment and performance. Journal of Business Ethics, $107,255-264$

Lewis, K. M. (2000). When leaders display emotion: How followers respond to negative emotional expression of male and female leaders. Journal of Organizational Behavior, 21, $221-234$.

Lightsey. R. L (1996) .What leads to wellness? The role of psychological resource in well being. The Journal of Counseling Psychology, 24, 658-735.

Lord, R. G. (1985). An information processing approach to social perception, leadership, and behavior in organizations. Research in Organizational Behavior, 7, 87-128. 
Lord, R. G., De Vader, C. L., \& Alliger, G. M. (1986). A meta-analysis of the relationship between personality traits and leadership perceptions: An application of validity generalization procedures. Journal of Applied Psychology, 71, 402-410.

Luft, J. (1984). Group processes: An introduction to group dynamics (3rd ed.). Palo Alto, CA: Mayfield.

Luthans, F. (2002). The need for and meaning of positive organizational behavior. Journal of Organizational Behavior, 23, 695-706.

Luthans, F., \& Avolio, B. J. (2003). Authentic leadership: A positive developmental approach. In K. S. Cameron, J. E. Dutton \& R. E. Quinn (Eds.), Positive organizational scholarship: Foundations for a new discipline (pp. 241-258). San Francisco: BerrettKoehler.

Lyubomirsky, S., Tkach, C., \& DiMatteo, M. R. (2006). What are the differences between happiness and self-esteem? Social Indicators Research, 78, 363-404.

Maertz, C. P., Jr., Griffeth, R. W., Campbell, N. S., \& Allen, D. G. (2007). The effects of perceived organizational support and perceived supervisor support on employee turn-over. Journal of Organizational Behavior, 28, 1059-1075.

Manion, J. (2000). Retaining current leaders. Health Forum Journal, 43, 24-27.

Mann, R. D. (1959). A review of the relationships between personality and performance in small groups. Psychological Bulletin, 56, 241-270.

Manz, C. C., \& Sims, H. P. (1984). Searching for the "unleader": Organizational member views on leading self-managed groups. Human Relations, 37, 409-424

Manz, C. C., \& Sims, H. P., Jr. (1991). Super leadership: Beyond the myth of heroic leadership. Organizational Dynamics, 19, 18-35.

Manz, C. C., \& Sims, H. P., Jr. (1993). Business without bosses: How self-managing teams are building high-performing companies. New York: Wiley.

Manz, C. C., \& Sims, H. P., Jr. (2001). The new Super Leadership: Leading others to lead themselves. San Francisco: Berrett-Koehler.

Maslach C, Schaufeli W.B. \& Leiter M. (2001). Job burnout. Annual Review of Psychology, 52, 397-422. 
Masson, R. C., Royal, M. A., Agnew, T. G., \& Fine, S. (2008). Leveraging employee engagement: The practical implications. Industrial and Organizational Psychology, 1, 5659.

Masterson, S. S. (2001). A trickle-down model of organizational justice: Relating employees' and customers' perceptions of and reactions to fairness. Journal of Applied Psychology, 86, 594-604.

Maurer, T. J., \& Lippstreu, M. (2008). Who will be committed to an organization that provides support for employee development? Journal of Management Development, 27, $328-347$.

Maurer, T. J., Pierce, H. R., \& Shore, L. M. (2002). Perceived beneficiary of employee development activity: A three-dimensional social exchange model. Academy of Management Review, 27, 432-444.

Mayo, M., Meindl, J. R., \& Pastor, J. (2003). Shared leadership in work teams. A social network approach. In C. L. Pearce \& J. A. Conger (Eds.), Shared leadership: Reframing the hows and whys of leadership (pp. 193-214). Thousand Oaks, CA: Sage.

McCall, M.W. (2010). Recasting leadership development. Industrial and Organizational Psychology: Perspectives on Science and Practice, 3, 3-19.

McColl-Kennedy, J. R., \& Anderson, R. D. (2002). Impact of leadership style and emotions on subordinate performance. The Leadership Quarterly, 13, 545-559.

McGregor, D. (1960). The human side of enterprise. New York: McGraw-Hill.

Mechanic, D. (1962). The sources of power for lower participants in complex organizations. Administrative Science Quarterly, 7, 349-364.

Mehra, A., Smith, B. R., Dixon, A. L., \& Robertson, B. (2006). Distributed leadership in teams: The network of leadership perceptions and team performance. The Leadership Quarterly, 17, 232-245.

Meichenbaum, D. (1977). Cognitive-behavior modification: An integrative approach. New York: Plenum Press.

Mesquita, B., \& Frijda, N. H. (1992). Cultural variations in emotions: A review.

Psychological Bulletin, 112, 179-204.

Mohrman, S. A., Cohen, S. G., \& Morhman, A. M., Jr. (1995). Designing team-based organizations: New forms for knowledge work. San Francisco: Jossey-Bass. 
Mulki, J. P., Jaramillo, F., and Locander, W. B. (2009), Critical role of leadership on ethical climate and salesperson behaviors. Journal of Business Ethics, 86, 125-141.

Murray, N., Sujan, H., Hirt, E. R., \& Sujan, M. (1990). The influence of mood on categorization: A cognitive flexibility interpretation. Journal of Personality and Social Psychology, 59, 411-425.

Neubert, M. J. (1999). Too much of a good thing or the more the merrier? Exploring the dispersion and gender composition of informal leadership in intact manufacturing teams. Small Group Research, 30, 635-646.

Neubert, M. J., \& Taggar, S. (2004). Pathways to informal leadership: The moderating role of gender on the relationship of individual differences and team member network centrality to informal leadership emergence. The Leadership Quarterly, 15, 175-194.

Neumann, R., \& Strack, F. (2000). Mood contagion: The automatic transfer of mood between persons. Journal of Personality and Social Psychology, 79, 211-223.

Ng, T. W. H., \& Feldman, D. C. (2008). The relationship of age to ten dimensions of job performance. Journal of Applied Psychology, 93, 392-423.

Oh, Se-Hyung. 2012. Leadership emergence in autonomous work teams: Who is more willing to lead. Social Behavior and Personality, 40, 1451-1464.

Ohlott, P. J., Ruderman, M. N., \& McCauley, C. D. (1994). Gender differences in managers' developmental job experiences. Academy of Management Journal, 37, 46-67.

Paglis, L. L., \& Green, S. G. (2002). Leadership self-efficacy and managers' motivation for leading change. Journal of Organizational Behavior, 23, 215-235.

Pearce, C. L. (1997). The determinants of change management team (CMT) effectiveness: A longitudinal investigation. Unpublished doctoral dissertation, University of Maryland, College Park.

Pearce, C. L. (2004). The future of leadership: Combining vertical and shared leadership to transform knowledge work. Academy of Management Executive, 18, 47-57.

Pearce, C. L., \& Conger, J. A. (2003). All those years ago: The historical underpinnings of shared leadership. In C. L. Pearce \& J. A. Conger (Eds.), Shared leadership: Reframing the hows and whys of leadership (pp. 1-18). Thousand Oaks, CA: Sage. 
Pearce, C. L., \& Manz, C. C. (2005). The new silver bullets of leadership: The importance of self- and shared leadership in knowledge work. Organizational Dynamics, $34,130-140$.

Pearce, C. L., \& Sims, H. P. Jr. (2000). Shared leadership: Toward a multi-level theory of leadership. In M. Beyerlein, D. Johnson, \& S. Beyerlein (Eds.), Advances in interdisciplinary studies of work teams (Vol. 7, pp. 115-139). New York, NY: JAI Press.

Pearce, C. L., \& Sims, H. P. (2002). Vertical versus shared leadership as predictors of the effectiveness of change management teams: An examination of aversive, directive, transactional, transformational, and empowering leader behaviors. Group Dynamics: Theory, Research, and Practice, 6, 172-197.

Pearce, C. L., Yoo, Y., \& Alavi, M. (2004). Leadership, social work and virtual teams: The relative influence of vertical versus shared leadership in the nonprofit sector. In R. E. Riggio, S. Smith-Orr, \& J. Shakely (Eds.), Improving leadership in nonprofit organizations (pp. 180-204). San Francisco, CA: Jossey-Bass.

Perry, M. L., Pearce, C. L., \& Sims, H. P. Jr. (1999). Empowered selling teams: How shared leadership can contribute to selling team outcomes. Journal of Personal Selling and Sales Management, 3, 35-51.

Pescosolido, A. T. (2002). Emergent leaders as managers of group emotion. The Leadership Quarterly, 13, 583-599.

Peterson, C. (2000). The future of optimism. American Psychologist, 55, 44-56.

Peterson, S. J., Walumbwa, F. O., Byron, K., \& Myrowitz, J. (2009). CEO positive psychological traits, transformational leadership, and firm performance in hightechnology start-up and established firms. Journal of Management, 35, 348-368.

Pitt-Catsouphes, Marcie, and Michael Smyer. Age and Generations Study, 2007-2008. ICPSR34837-v1. Ann Arbor, MI: Inter-university Consortium for Political and Social Research [distributor], 2013-10-07.

Podsakoff, P.M., MacKenzie, S.B., Moorman, R.H., \& Fetter, R. (1990).

Transformational leader behaviors and their effects on followers' trust in leader, satisfaction, and organizational citizenship behaviors. The Leadership Quarterly, 1, 107142.

Powell, G. N. (1990). One more time: Do female and male managers differ? Academy of Management Executive, 4, 68-75. 
Raghunathan, R., \& Pham, M. T. (1999). All negative moods are not equal: Motivational influences of anxiety and sadness on decision-making. Organizational Behavior and Human Decision Processes, 79, 56-77.

Raymo, J. M., Warren, J. R., Sweeney, M. M., Hauser, R. M., \& Ho, J.-H. (2010). Laterlife employment preferences and outcomes: The role of midlife work experiences. Research on Aging, 32, 419-466.

Reinsch, J. M., Rosenblum, L. A., Rubin, D. B., \& Schulsinger, M. F. (1991). Sex differences in developmental milestones during the first year of life. Journal of Psychology \& Human Sexuality, 4, 19-36.

Rhoades, L. and Eisenberger, R. (2002), Perceived organizational support: A review of the literature. Journal of Applied Psychology, 87, 698-714.

Riaz, A., \& Haider, M. H. (2010). Role of transformational and transactional leadership on job satisfaction and career satisfaction. Business and Economic Horizons, 1, 29-38.

Rich B. L., LePine, J. A., Crawford, E.R. (2010). Job engagement: Antecedents and effects on job performance. Academy of Management Journal, 53, 617-635.

Ridgeway, C. L. (1992). Gender, interaction, and inequality. NY: Springer-Velag.

Roberson, Q. M., \& Colquitt, J. A. (2005). Shared and configural justice: A social network model of justice in teams. Academy of Management Review, 30, 595-607.

Roseman, J. J. (1991). Appraisal determinants of discrete emotions. Cognition and Emotion, 5, 161-200.

Roseman, I. J., \& Evdokas, A. (2004). Appraisals cause experienced emotions: Experimental evidence. Cognition \& Emotion, 18, 1-28.

Rosenhan, D. L., Salovey, P., \& Hargis, K. (1981). The joys of helping: Focus of attention mediates the impact of positive affect on altruism. Journal of Personality and Social Psychology, 40, 899-905.

Rost, J. C. (1993). Leadership for the twenty-first century. Westport, CT: Praeger.

Salovey, P., \& Birnbaum, D. (1989). Influence of mood on health-relevant cognitions. Journal of Personality and Social Psychology, 57, 539-551. 
Salovey, P., Hsee, C. K., \& Mayer, J. D.(1993). Emotional intelligence and selfregulation.In D. M.Wegner \& J. W. Pennebaker, Handbook of mental control (pp. 258277). Englewood Cliffs, NJ: Prentice Hall.

Sarros, J. C., Cooper, B. K. and Hartican, A.M. (2006). Leadership and character. Leadership and Organization Development Journal, 27, 682-689.

Schaubroeck, J., Lam, S. S. K., \& Cha, S. E. (2007). Embracing transformational leadership: Team values and the impact of leader behavior on team performance. Journal of Applied Psychology, 92, 1020-1030.

Schaufeli, W. B., Bakker, A. B., \& Salanova, M. (2006). The measurement of work engagement with a short questionnaire: A cross-national study. Educational and Psychological Measurement, 66, 701-716.

Schaufeli, W. B., Salanova, M., Gonzalez-Roma, V., \& Bakker, A.B. (2002). The measurement of engagement and burnout: A two sample confirmatory factor analytic approach. Journal of Happiness Studies, 3, 71-92.

Schaufeli, W. B., \& Salanova, M. (2007). Work engagement: An emerging psychological concept and its implications for organizations. In S. W. Gilliland, D. D. Steiner, \& D. P. Skarlicki (Eds.), Research in social issues in management: Managing social and ethical issues in organizations (pp. 135-177). Greenwich, CT: Information Age Publishers.

Schein, E. H. (1978). Career dynamics: Matching individuals and organizational needs. Boston, MA: Addison-Wesley.

Scheier, M. F., \& Carver, C. S. (1985). Optimism, coping, and health: Assessment and implications of generalized outcome expectancies. Health Psychology, 4, 219-247.

Schneer, J. A., \& Reitman, F. (1990). Effects of employment gaps on the careers of M.B.A.'s: More damaging for men than for women? Academy of Management Journal, 33, 391-406.

Schneier, C. E., \& Goktepe, J. R. (1983). Issues in emergent leadership: The contingency model of leadership, leader sex, leader behavior. In H. H. Blumberg, A. P. Hare, V. Kent, \& M. F. Davies (Eds.), Small groups and social interaction. (pp. 413-421) Chichester, UK: Wiley.

Shanock, L. R., \& Eisenberger, R. (2006). When supervisors feel supported:

Relationships with subordinates' perceived supervisor support, perceived organizational support, and performance. Journal of Applied Psychology, 91, 689-695. 
Sherif, M., \& Sherif, C. (1953). Groups in harmony and tension. New York: Harper.

Simons, T. L. (1999). Behavioral integrity as a critical ingredient for transformational leadership. Journal of Organizational Change Management, 12, 89-104.

Sinclair, R. C. (1988). Mood, categorization breadth and performance appraisal: The effects of order of information acquisition and affective state on halo, accuracy, information retrieval, and evaluations. Organizational Behavior and Human Decision Processes, 42, 22-46.

Sivasubramaniam, N., Murry, W. D., Avolio, B. J., \& Jung, D. I. (2002). A longitudinal model of the effects of team leadership and group potency on group performance. Group \& Organization Management, 27, 66-96.

Small, E. E. and Rentsch, J. R. (2010). Shared leadership in teams: A matter of distribution. Journal of Personnel Psychology, 9, 203-211.

Song, J. H., Kolb, J. A., Lee, U. H., \& Kim, H. K. (2012). Role of transformational leadership in effective organizational knowledge creation practices: Mediating effects of employees' work engagement. Human Resource Development Quarterly, 23, 65-101.

Sorrentino, R. M., \& Field, N. (1986). Emergent leadership over time: The functional value of positive motivation. Journal of Personality and Social Psychology, 50, 1091-1099.

Sparrowe, R. T., Liden, R. C., Wayne, S. J., \& Kraimer, M. L. (2001). Social networks and the performance of individuals and groups. Academy of Management Journal, 44, $316-325$.

Spillane, J. P., Halverson, R., \& Diamond, J. B. (2000). Investigating school leadership practice: a distributed perspective. Educational Researcher, 30, $23-28$.

Spreitzer, G. M., \& Quinn, R. E. (1996). Empowering middle managers to be transformational leaders. Journal of Applied Behavioral Science, 32, 237-261.

Strathdee, R., \& Hughes, D. (2001). The national qualifications framework and the pessimistic worker effect. New Zealand Journal of Educational Studies, 36, 155-169.

Streufert, S., Pogash, R., Piasecki, M., \& Post, G. M. (1990). Age and management team performance. Psychology and Aging, 5, 551-559. 
Steyrer, J, Schiffinger, M. and Lang, R. (2008). Organizational commitment-A missing link between leadership behavior and organizational performance? Scandinavian Journal of Management, 24, 364-374.

Sutton, G, and Griffin, M. A. (2004). Integrating expectations, experiences, and psychological contract violations: A longitudinal study of new professionals. Journal of Occupational and Organizational Psychology, 77, 493-514.

Taggar, S., Hackett, R., \& Saha, S. (1999). Leadership emergence in autonomous work teams: Antecedents and outcomes. Personnel Psychology, 52, 899-926.

Taylor, F. W. (1911). The principles of scientific management. New York: Harper \& Brothers.

Thiel, C. E., Connelly, S., \& Griffith, J. A. (2012). Leadership and emotion management for complex tasks: Different emotions, different strategies. The Leadership Quarterly, 23, 517-533.

Thorenson, E. E., \& Mahoney, M. J. (1974). Behavioral self-control. New York: Holt, Rinehart \& Winston.

Van Engen, M. L., Van der Leeden, R., \& Willemsen, T. M. (2001). Gender, context and leadership styles: A field study. Journal of Occupational and Organizational Psychology, $74,581-598$.

Van Iddekinge C. H., Ferris G.R, \& Heffner T. S. (2009). Test of a multistage model of distal and proximal antecedents of leader performance. Personnel Psychology, 62, 463495.

Vecchio, R. P. (1993). The impact of differences in subordinate and supervisor age on attitudes and performance. Psychology and Aging, 8, 112-119.

Vecchio, R. P. (2002). Leadership and gender advantage. The Leadership Quarterly, 13, 643-671.

Walter, F., \& Scheibe, S. (2013). A literature review and emotion-based model of age and leadership: New directions for the trait approach. The Leadership Quarterly, 24, 882-901.

Wang, D., Waldman D. A. and Zhang, Z. (2014). A meta-analysis of shared leadership and team effectiveness. Journal of Applied Psychology, 99, 181-198.

Wayne, S. J., Shore, L. M., \& Liden, R. C. (1997). Perceived organizational support and leader-member exchange: A social exchange perspective. Academy of Management Journal, 40, 82-111. 
Wheelan, S. A., \& Johnston, F. (1996). The role of informal member leaders in a system containing formal leaders. Small Group Research, 27, 33-55.

Whitman, D. S., Caleo, S., Carpenter, N. C., Horner, M. T., \& Bernerth, J. B. (2012). Fairness at the collective level: A meta-analytic examination of the consequences and boundary conditions of organizational justice climate. Journal of Applied Psychology, 97, 776-791.

Williams, L. J., \& Anderson, S. E. 1991. Job satisfaction and organizational commitment as predictors of citizenship and in-role behaviors. Journal of Management, 17, 601-617.

Wilson, E. O. (1992). Sociobiology. Cambridge, MA: Harvard University Press.

Yeatts, D. E. and Hyten, C. (1998). High performing self managed work teams: A comparison of theory to practice. Thousand Oaks: Sage Publications.

Youssef, C. M., \& Luthans, F. (2007). Positive organizational behavior in the workplace: The impact of hope, optimism, and resiliency. Journal of Management, 33, 774-800.

Yukl, G. (1981), Leadership in organizations. Englewood Cliffs: Prentice-Hall.

Yukl, G.A. (1989). Managerial leadership: A review of theory and research. Journal of Management, 15, 251-289.

Yukl, G. (1998). Leadership in organizations, 4th ed., Englewood Cliffs: Prentice-Hall.

Yukl, G. (1999). An evaluation of conceptual weaknesses in transformational and charismatic leadership theories. The Leadership Quarterly, 10, 285-305.

Yukl, G., \& Falbe, C. M. (1990). Influence tactics in upward, downward, and lateral influence attempts. Journal of Applied Psychology, 75, 132-140.

Yukl, G., \& Falbe, C. M. (1991).The importance of different power sources in downward and lateral relations. Journal of Applied Psychology, 76, 416-423.

Zaccaro, S. J., Rittman, A. L., \& Marks, M. A. (2001). Team leadership. The Leadership Quarterly, 12, 451-483.

Zacher, H., Heusner, S., Schmitz, M., Zwierzanska, M. M., \& Frese, M. (2010). Focus on opportunities as a mediator of the relationships between age, job complexity, and work performance. Journal of Vocational Behavior, 76, 374-386. 
Zacher, H., Rosing, K., \& Frese, M. (2011). Age and leadership: The moderating role of legacy beliefs. The Leadership Quarterly, 22, 43-50.

Zhu, W., Chew, I., and Spangler, W., (2005). CEO transformational leadership and organizational outcomes: The mediating role of human-capital-enhancing human resource management. The Leadership Quarterly, 16, 39-52. 


\section{APPENDICES}

1. Demographic Information (Employee)

\begin{tabular}{|l|l|}
\hline \multicolumn{1}{|c|}{ Questions } & \multicolumn{1}{|c|}{ Choices } \\
\hline Q70. Are you ... & $\begin{array}{l}\text { 1. Male } \\
\text { 2. Female }\end{array}$ \\
\hline Q71. In what year were you born? & $19 \_$(Enter Two Digit Numeric Response) \\
\hline Q74. What is the highest grade you have & $\begin{array}{l}\text { 1. Less than high school } \\
\text { completed in school... }\end{array}$ \\
& $\begin{array}{l}\text { 2. High school diploma or GED } \\
\text { 3. Some college }\end{array}$ \\
& 5. Bachelor's degree or higher \\
& 6. Some graduate training or graduate \\
& 7. Graduate degree \\
\hline
\end{tabular}

2. Formal Leadership

\begin{tabular}{|c|l|}
\hline Questions & \multicolumn{1}{|c|}{ Choices } \\
\hline Do you have any supervisory responsibilities? & $\begin{array}{l}0 . \text { No } \\
1 . \quad \text { Yes }\end{array}$ \\
\hline
\end{tabular}

\section{Work Experience}

\begin{tabular}{|l|l|}
\hline \multicolumn{1}{|c|}{ Questions } & \multicolumn{1}{|c|}{ Choices } \\
\hline How many years have you been with & [Insert Numeric Response] years \\
[Organization Name], in total? (Accepts & \\
decimals) & \\
\hline
\end{tabular}

4. Informal Leadership

\begin{tabular}{|c|c|}
\hline Questions & Choices \\
\hline $\begin{array}{l}\text { Q28A. I have a say in the way my work group } \\
\text { performs its tasks. }\end{array}$ & \multirow{4}{*}{$\begin{array}{l}\text { 1. Strongly disagree } \\
\text { 2. Disagree } \\
\text { 3. Somewhat disagree } \\
\text { 4. Somewhat agree } \\
\text { 5. Agree } \\
\text { 6. Strongly agree }\end{array}$} \\
\hline $\begin{array}{l}\text { Q28B. My coworkers openly share work - } \\
\text { related information with me. }\end{array}$ & \\
\hline $\begin{array}{l}\text { Q28D. I am able to influence decisions that } \\
\text { affect my work group }\end{array}$ & \\
\hline $\begin{array}{l}\text { Q28F. I am usually invited to important } \\
\text { meetings in my organization. }\end{array}$ & \\
\hline
\end{tabular}




\section{Organizational Support for Development}

\begin{tabular}{|l|l|}
\hline \multicolumn{1}{|c|}{ Questions } & \multicolumn{1}{c|}{ Choices } \\
\hline $\begin{array}{l}\text { Q15A. My company promotes the continuous } \\
\text { learning and development of all employees. }\end{array}$ & 1. Strongly disagree \\
\cline { 1 - 2 } $\begin{array}{l}\text { Q15B. I am given a real opportunity to improve } \\
\text { my skills at this company through education } \\
\text { and training programs }\end{array}$ & $\begin{array}{l}\text { 3. Somewhat disagree } \\
\text { 4. Somewhat agree } \\
\text { 515C. I am satisfied with the training and } \\
\begin{array}{ll}\text { Q15ee } \\
\text { development programs available to me }\end{array}\end{array}$ \\
\hline
\end{tabular}

\section{Team effectiveness}

\begin{tabular}{|c|c|}
\hline Questions & Choices \\
\hline $\begin{array}{l}\text { Q29H. The members of my work team make } \\
\text { good use of each employee's talent. }\end{array}$ & \multirow{4}{*}{$\begin{array}{l}\text { 1. Strongly disagree } \\
\text { 2. Disagree } \\
\text { 3. Somewhat disagree } \\
\text { 4. Somewhat agree } \\
\text { 5. Agree } \\
\text { 6. Strongly agree }\end{array}$} \\
\hline $\begin{array}{l}\text { Q29I. The members of my work team use } \\
\text { effective communication strategies. }\end{array}$ & \\
\hline $\begin{array}{l}\text { Q29J. The members of my work team use the } \\
\text { resources available in an effective way. }\end{array}$ & \\
\hline $\begin{array}{l}\text { Q29K. The members of my work team manage } \\
\text { conflict within the team effectively. }\end{array}$ & \\
\hline
\end{tabular}

\section{Individual Performance}

\begin{tabular}{|l|l|}
\hline \multicolumn{1}{|c|}{ Questions } & \multicolumn{1}{|c|}{ Choices } \\
\hline $\begin{array}{l}\text { Q58a. How would you rate your job } \\
\text { performance, as an individual employee? For } \\
\text { example, how well do you perform your job } \\
\text { compared to other members of your team> }\end{array}$ & $\begin{array}{l}\text { 1. Very Poor } \\
\text { 2. Poor }\end{array}$ \\
\cline { 1 - 1 } $\begin{array}{l}\text { Q58b. Think about your most recent } \\
\text { assessment of your job performance or the most } \\
\text { recent time you received feedback from your } \\
\text { supervisor. How do you think your supervisor } \\
\text { would rate your performance, in comparison to } \\
\text { other members of your team? }\end{array}$ & 5. Excellent \\
\cline { 1 - 1 } $\begin{array}{l}\text { Q58c. How would you rate your performance } \\
\text { as a work team member? }\end{array}$ \\
\hline
\end{tabular}




\section{Individual Job Satisfaction}

\begin{tabular}{|c|c|}
\hline Questions & Choices \\
\hline $\begin{array}{l}\text { Q46e. I am satisfied with the success I have } \\
\text { achieved in my career. }\end{array}$ & \multirow{5}{*}{$\begin{array}{l}\text { 1. Strongly disagree } \\
\text { 2. Disagree } \\
\text { 3. Somewhat disagree } \\
\text { 4. Somewhat agree } \\
\text { 5. Agree } \\
\text { 6. Strongly agree }\end{array}$} \\
\hline $\begin{array}{l}\text { Q46f. I am satisfied with the progress I have } \\
\text { made toward meeting my overall career goals }\end{array}$ & \\
\hline $\begin{array}{l}\text { Q46g. I am satisfied with the progress I have } \\
\text { made toward meeting my goals for } \\
\text { advancement. }\end{array}$ & \\
\hline $\begin{array}{l}\text { Q46h. I am satisfied with the progress I have } \\
\text { made toward meeting my financial objectives. }\end{array}$ & \\
\hline $\begin{array}{l}\text { Q46i. I am satisfied with the progress I have } \\
\text { made toward my goals for the development of } \\
\text { new skills. }\end{array}$ & \\
\hline
\end{tabular}

\section{Work Engagement}

\begin{tabular}{|l|l|}
\hline \multicolumn{1}{|c|}{ Questions } & \multicolumn{1}{c|}{ Choices } \\
\hline $\begin{array}{l}\text { Q55d. When I get up in the morning, I feel like } \\
\text { going to work }\end{array}$ & $\begin{array}{l}\text { 1. Never } \\
\text { 2. Almost never-A few times a year or less }\end{array}$ \\
\hline Q55e. I am enthusiastic about my job. & 3. Rarely-Once a month or less \\
\hline Q55f. I am immersed in my work & 4. Sometimes-A few times a month \\
& $\begin{array}{l}\text { 5. Often-Once a week } \\
\text { 6. Very often-A few times a week } \\
\text { 7. Always-Every day }\end{array}$ \\
\hline
\end{tabular}

\section{Turnover Intention}

\begin{tabular}{|l|l|}
\hline \multicolumn{1}{|c|}{ Questions } & \multicolumn{1}{c|}{ Choices } \\
\hline Q56b. It would take a lot to get me to leave my & 1. Strongly disagree \\
organization & 2. Disagree \\
& 3. Somewhat disagree \\
& 4. Somewhat agree \\
& 5. Agree \\
& 6. Strongly agree \\
\hline Q56d. Compared to other organization I know & 1. Strongly disagree \\
about, I think my organization is a great place & 2. Disagree \\
to work. & 3. Somewhat disagree \\
& 4. Somewhat agree \\
& 5. Agree \\
\hline
\end{tabular}


11. Positive Feeling (Optimistic Viewpoint)

\begin{tabular}{|c|c|}
\hline Questions & Choices \\
\hline $\begin{array}{l}\text { Q49a. I am confident I get the success I deserve } \\
\text { in life }\end{array}$ & \multirow{6}{*}{$\begin{array}{l}\text { 1. Strongly disagree } \\
\text { 2. Disagree } \\
\text { 3. Somewhat disagree } \\
\text { 4. Somewhat agree } \\
\text { 5. Agree } \\
\text { 6. Strongly agree }\end{array}$} \\
\hline Q49c. When I try, I really succeed. & \\
\hline Q49e. I complete tasks successfully. & \\
\hline Q49g. Overall, I am satisfied with my life & \\
\hline Q49i. I determine what will happen in my life & \\
\hline $\begin{array}{l}\text { Q49k. I am capable of coping with most of my } \\
\text { problems. }\end{array}$ & \\
\hline
\end{tabular}

\section{Negative Feeling (Pessimistic Viewpoint)}

\begin{tabular}{|c|c|}
\hline Questions & Choices \\
\hline Q49b. Sometimes I feel depressed. & \multirow{6}{*}{$\begin{array}{l}\text { 1. Strongly disagree } \\
\text { 2. Disagree } \\
\text { 3. Somewhat disagree } \\
\text { 4. Somewhat agree } \\
\text { 5. Agree } \\
\text { 6. Strongly agree }\end{array}$} \\
\hline Q49d. Sometimes when I fail, I feel worthless. & \\
\hline $\begin{array}{l}\text { Q49f. Sometimes, I do not feel in control of my } \\
\text { work. }\end{array}$ & \\
\hline $\begin{array}{l}\text { Q49h. I am filled with doubts about my } \\
\text { competence. }\end{array}$ & \\
\hline $\begin{array}{l}\text { Q49j. I do not feel in control of my success in } \\
\text { my career. }\end{array}$ & \\
\hline $\begin{array}{l}\text { Q491. There are times when things look pretty } \\
\text { bleak and hopeless to me. }\end{array}$ & \\
\hline
\end{tabular}


VITA

KYUNGCHOOL JOE

2000

B.A., Business

Hanyang University

Seoul, South Korea

$2001-2003$

MBA

Sungkyunkwan University

Seoul, South Korea

$2003-2008$

Researcher

Korea Rural Economic Institute (KREI)

Seoul, South Korea

$2010-2012$

MBA

University of Central Florida

Orlando, FL

$2012-2016$

Doctoral Candidate

Florida International University

Miami, Florida

Publication \& Presentations

Kyung, Joe and Soung-hun Kim (2007) Factors causing the withdrawal of foreign retaile rs from Korean retail market. Journal of Rural Development, 30(5), 61-81

Kyung, Joe (2014) Developing and Validating the Measures of Long-Term Orientation an $d$ Their Scales (2014 AIB Conference Presentation)

Kyung, Joe (2005) Strengthening of Market Research for Development of Agricultural Ex port Market in Korea (Asia Productivity Organization Bangkok Seminar) 